\title{
CAROTENOID-PROTEIN COMPLEXES
}

\author{
P. F. ZAGALSKY \\ Department of Biochemistry, Bedford College, Regent's Park, London, NW1 4NS, UK
}

\begin{abstract}
A survey of carotenoid-protein complexes is presented. Distinction is made between astaxanthin-proteins in which the absorption band of the carotenoid is unaltered in shape, and carotenoid-lipoglycoprotein complexes. The proposal by Buchwald and Jencks ${ }^{79}$ that the carotenoid is twisted about the double bonds of the polyene chain, is discussed and sustained for astaxanthin-proteins. A mode of binding for the carotenoid in these complexes is proposed, involving hydrogen-bonding of keto groups of the polyene to imide groups of peptide bonds of the apoprotein.
\end{abstract}

\section{INTRODUCTION}

This article, following earlier reviews, ${ }^{1,2}$ will deal primarily with carotenoid-protein complexes in invertebrates. While they occur elsewhere, ${ }^{3,4,43,44}$ it is in the invertebrate phyla that they are widespread. A brief account of "vitamin A-proteins", and plant and bacterial carotenoidprotein complexes is included for completeness.

In invertebrates, carotenoids occur in several different states. They may exist as lipid dispersions, often within chromatophores. $^{5-7}$ Vivid and varied coloration may be provided by carotenoids bound to structural elements as, for example, to chitin in the carapace of Crustacea, ${ }^{8,9}$ to the scleroproteins of feathers ${ }^{10,11}$ and to calcium carbonate in corals. ${ }^{12,13}$ Carotenoids are also found as watersoluble complexes with protein. Carotenoid-protein complexes are particularly frequent in the Crustacea, and it is to the complexes of this group that attention has been directed and from which most examples are taken. The taxonomic distribution and anatomical location of carotenoid-protein complexes within animals of the neuston $^{14}$ and decapod Crustacea ${ }^{9}$ and their possible functions, such as cryptic coloration, within these groups and within the zooplankton, ${ }^{15}$ have been amply reviewed.

Two quite different types of carotenoid-protein complex may be distinguished: those in which the carotenoid is associated with a lipo(glyco)protein and those where it is bound stoichiometrically to a simple protein or glycoprotein.

\section{CAROTENOID-LIPO(GLYCO)PROTEINS \\ Nature of the combinations}

The specificity shown by the lipoprotein for the carotenoid component and the nature of the binding, reflected in the spectral characteristics of the complexes, show great variety. In some combinations, such as those in eggs and ovary of Cancer pagurus $\left(\lambda_{\max } 470,490 \mathrm{~nm}\right)^{16}$, in eggs, ovary and blood of Emerita analoga $\left(\lambda_{\max }\right.$ $463,472 \mathrm{~nm})^{17}$ and in eggs of Pagurus prideauxi $\left(\lambda_{\max } 470,495 \mathrm{~nm}\right)^{156}$, selectivity in binding is not apparent. All the carotenoids of the whole tissue are present and in about the same relative proportions. In other instances, as in the ovary of Pecten maximus $\left(\lambda_{\max } 472,498 \mathrm{~nm}\right)^{16}$ and plasma of the birds Ajaia ajaja $\left(\lambda_{\max } 480 \mathrm{~nm}\right)^{18}$ and Guara

$†$ The carotenoid-binding specificity of the egg lipoprotein of $P$. bernhardus apparently differs from that of the ovary lipoprotein. The egg carotenoid-lipoprotein complexes of both $P$. barnhardus and $P$. prideauxi have astaxanthin as the major carotenoid component. Substantial amounts of $\beta$-carotene and, possibly, traces of astaxanthin esters are also present in the complexes. ${ }^{156}$ rubra $\left(\lambda_{\max } 460 \mathrm{~nm}\right)^{11}$, polar carotenoids are preferentially combined. In these cases, the bathochromic shift in the absorption spectra (10-25 nm compared with solutions in hexane) can be explained by refractive index effects associated with dissolution of the carotenoids in the lipid or protein components of the lipoproteins. ${ }^{18,79,82}$ Part of the carotenoid fraction may nevertheless be associated more specifically. It is of interest that for the carotenoidtransporting low-density lipoprotein ${ }^{4}$ of human serum, the circular dichroism induced in the absorption of the carotenoid on cooling has been attributed to its interactions with the protein or to phase transition in the lipid. ${ }^{19}$

A single carotenoid prosthetic group, which may be astaxanthin (Homarus gammarus (L.), ${ }_{1}^{1}$ Plesionika edwardsi ${ }^{16}$ Acanthephyra spp., ${ }^{20}$ Giganto cypris, ${ }^{21}$ Lepas spp. $^{1,22,31}$ and Pollicipes polymerus ${ }^{23}$ ), canthaxanthin (Artemia salina ${ }^{24}$ and Branchipus stagnalis $\left.(L)^{25}\right)$, an epiphasic astaxanthin ester $\left((E u)\right.$ Pagurus bernhardus $\left.{ }^{26}\right), \dagger$ $\beta$-carotene (Callinectes sapidus) $)^{60}$ or a " $\beta$-carotene-like" carotenoid (Procambarus sp.) ${ }^{27}$, is found in many red, green and blue egg and ovary carotenoid-protein complexes. Traces of other carotenoids, however, are often also present ${ }^{20,23,28,60}$ and it is debatable whether the apparent specificity is due to the predominance of a single carotenoid in the tissue $\left(H\right.$. gammarus ${ }^{28}$ Lepas spp., ${ }^{29}$ Acanthephyra spp. $^{20}$ and $C$. sapidus ${ }^{60}$ ) as a result of metabolic selectivity, ${ }^{20}$ or to preferential selection of a particular carotenoid during transport and deposition. The absorption spectrum of the carotenoid in the complexes may have the same spectral characteristics (oscillator strength, half-band width) as the carotenoid dissolved in hexane, with only a small change in the position of the absorption maximum (A. salina, $\lambda_{\max } 470 \mathrm{~nm}^{24}$; Acanthephyra spp. $.^{20}, \lambda_{\max } 486-498 \mathrm{~nm} ; P$. polymerus sp., $\lambda_{\max } 470 \mathrm{~nm}^{23}$ ). Occasionally the smooth absorption band of the prosthetic group may become a triple-peaked band (e.g. in the red complex of Giganto cypris $^{21}$ ) as for ovorubin, the proteinase-inhibiting ${ }^{30}$ astaxanthinglycoprotein of the eggs of the prosobranch Pomacea canaliculata. $^{1}$ Blue complexes, where the absorption maximum of the keto-carotenoid is bathochromically shifted and altered in shape (usually double-peaked) are common ( $P$. edwarsi, $\lambda_{\max } 632,(670) \mathrm{nm} ;{ }^{16}$ Lepas spp. $\lambda_{\max } 600 \mathrm{~nm}^{1}$ B. stagnalis $\lambda_{\max } 625,(675) \mathrm{nm}^{25}$ ), while in the spectrum of the green complex of $H$. gammarus (and Homarus americanus ${ }^{41}$ ), ovoverdin $\lambda_{\max } 463-468$, 645$670 \mathrm{~nm} \mathrm{~nm}),{ }^{1,28,41}$ and the purple complex of $P$. bernhardus $\left(\lambda_{\max } 465,495,580 \mathrm{~nm}\right)^{26}$ absorption bands, altered in shape, occur both above and below (or close to) the band of the free carotenoid. 
The green carotenoid-lipoglycoproteins in anostracan blood (Branchipus stagnalis (L.), Branchinecta packardi (Pearse), Tanymastix lacunae (Guérin) and Chirocephalus diaphanus (Prévost) $)^{33}$ and isopod cuticle (Idotea montereyensis ${ }^{34}$ and Idotea resecata ${ }^{35}$ ) and epidermis (Idotea granulosa ${ }^{36}$ ) owe their colour to incorporation into the complexes of the complete mixture of tissue carotenoids. The absorption spectra show maxima in the $370,400-500$ and $680 \mathrm{~nm}$ regions. In these, it is probable that different modes of binding of the carotenoid exist, for mild treatment, which removes some lipid components, eliminates selectively the $400-500 \mathrm{~nm}$ absorption band. It is suggested that lipid-associated carotenoids are responsible for the $400-500 \mathrm{~nm}$ absorption, while the maxima in the 370 and $680 \mathrm{~nm}$ regions arise from more firmly bound canthaxanthin. ${ }^{33-36}$ These absorption bands have different spectral characteristics (half-band width) to those of the carotenoid dissolved in hexane. The green pigment of the carapace of Carcinas maenas $\left(\lambda_{\max } 460,625\right)$ similarly show absorption bands above and below that of the free prosthetic group, astaxanthin; ${ }^{1}$ the composition of the complex has not been reported. Different modes of binding of carotenoid occur also in the egg and ovary complexes of $P$. bernhardus ${ }^{26}$ and Cyclops vernalis. ${ }^{37}$

The role of the carotenoid and its mode of binding in these complexes are uncertain. It has been pointed out $^{17,37-41}$ that the amount of carotenoid in the lipoproteins, and possibly even the nature of the carotenoid, ${ }^{40}$ depends on diet and environmental factors, which influence the availability of carotenoid at vitellogenesis; stoichiometry of combination has seldom been verified and no deleterious effects of carotenoid depletion have been substantiated..$^{39}$ Although hatchability ${ }^{42}$ of eggs and viability of naupliii ${ }^{32}$ may be impaired in animals fed on synthetic diets, this cannot be attributed solely to lack of carotenoids. If definite sites for the carotenoid exist in the proteins, these, as for the vertebrate carotenoidlipoproteins, ${ }^{43,44}$ need not be filled. ${ }^{41}$ The approximate stoichiometry in ovoverdin ${ }^{1,28}$ and in the egg carotenoidlipoprotein complexes of Lepas sp. ${ }^{31}$ and $B$. stagnalis ${ }^{25}$ may be fortuitous, and the alteration in the spectrum of the associated keto-carotenoid in these and similar complexes could merely reflect the high polarisability of the polyene. ${ }^{41}$ However, the selectivity of association in some of the proteins and the effects of disruption and reconstitution of the carotenoid-lipoprotein linkage (for the complexes of $\hat{H}$. gammarus, Lepas spp. and $P$. bernhardus $)^{1}$ suggests that the interaction involves more than passive solution in the lipoprotein.

The instability of the carotenoid-lipoprotein linkage is well documented. ${ }^{1}$ Exposure of the proteins to intense light, heat, metal ions or even storage can result in alterations in the visible absorption spectra. Ionic conditions are sometimes found important for the stability of the carotenoid linkage; solutions of the blue lipoprotein complex of $B$. stagnalis immediately turn red unless chloride ions are present. ${ }^{25}$ Slight alterations of $\mathrm{pH}$ may also affect the spectral characteristics; ${ }^{41}$ solutions of the proteins of Procambarus spp. turn from brown to orange, reversibly, on changing the $\mathrm{pH}$ from 7 to $8^{27}$, the purple Sesarma reticulatum pigment becomes orange at $\mathrm{pH} 7.5^{41}$ and the purple complex of $P$. bernhardus rapidly loses its

†The presence of protein-bound phosphorus previously reported, ${ }^{16}$ was the result of incomplete lipid extractions of the freeze-dried samples; the phospholipid and total lipid contents quoted in the paper should be increased accordingly.
$580 \mathrm{~nm}$ absorption band even at $\mathrm{pH} 7 .^{26}$ Hypochromicity effects, which may be explained by twisting of the polyene about the single bonds, ${ }^{109}$ have been reported in some complexes. ${ }^{41}$ The extinction of the carotenoid in the egg lipoglycoprotein of $P$. prideauxi is, however, almost unaltered in the combination. ${ }^{51}$

\section{Lipovitellins and haemolymph lipoglycoproteins}

The high-density lipoglycoproteins, with which most of the carotenoid present in crustacean eggs and ovary may be associated, ${ }^{1,20,29}$ have been termed crustacean lipovitellins, in analogy with vertebrate lipovitellins. ${ }^{41}$ Purification of the lipoproteins by density gradient and other methods is preferred; ${ }^{24,27,41}$ ion-exchange procedures, which can result in removal of lipid and carotenoid, ${ }^{23,33-36}$ are to be avoided unless special precautions are taken. ${ }^{45}$ The proteins "age" on storage even in the unextracted state. ${ }^{20,41,47}$

The compositions of several crustacean lipovitellins have been investigated and points of similarity revealed. ${ }^{16,20,27,41,60}$ They contain $27-35 \%$ lipid, a small carbohydrate component and, in contrast to vertebrate lipovitellins, ${ }^{43}$ no protein-bound phosphorus. $\dagger$ In most cases, the lipid component consists largely of phospholipid $^{16,27}$ with unusual fatty acid composition ${ }^{27}$ and smaller quantities of cholesterol and triglycerides, ${ }^{16}$ although neutral lipid and phospholipid occur in equal proportion in lipovitellins of Acanthephyra $\mathrm{spp}^{20}$ The decapod lipovitellins are of similar size, fairly symmetrical in shape and of molecular weight $3.3-3.7 \times 10^{5} .27,41$ Lipovitellins of other invertebrates $\left(P\right.$. maximus $;^{16} B$. stagnalis $^{25}$ ) may be larger or more asymmetrical. Dissociation-reassociation phenomena are observed at low protein concentration. ${ }^{41}$ On treatment with sodium dodecylsulphate, more extensive degradation of the lipovitellins of Procambarus sp., ${ }^{27}$ Lepas sp., ${ }^{51} H$ gammarus, ${ }^{51} P$. maximus ${ }^{51}$ and $B$. stagnalis ${ }^{25}$ is obtained than of amphibian, ${ }^{48}$ avian $^{49}$ or insect ${ }^{50}$ lipovitellins. It should be noted that the electrophoretic patterns obtained depend on the exact conditions of incubation; ${ }^{51}$ divergent results have been reported for other lipoproteins. ${ }^{52}$

The amino acid compositions of crustacean vitellins show no unusual features other than high contents of helix-breaking ${ }^{118,119}$ amino acids (serine and proline) (Fig. 1). They appear to be homologous proteins with similar contents of non-polar, polar and other categories of amino acids. ${ }^{56}$ The compositions are typical of other lipovitellins and soluble lipoproteins (Table 1). An estimate of relatedness can be made by calculating the values of $S \Delta \phi$ (differences in mol\% content of each amino acid squared and summed) for pairs of the proteins. ${ }^{57,58}$ Unrelated proteins have $S \Delta \phi$ values of more than 50 and almost invariably more than $100 . S \Delta \phi$ values for pairs of vitellins indicate that the crustacean proteins are closely related to each other and to analogous vitellins (Table 2). Their apparent resemblance to the carotenoid-transporting low-density lipoprotein ${ }^{4}$ of human serum $\left(\mathrm{LDL}_{\mathrm{s}}\right)$, and their distinction from the high-density serum lipoprotein $\left(\mathrm{HDL}_{s}\right)$, may provide an insight into their structure. The protein component of $\mathrm{LDL}_{s}$ is thought to interact specifically with the cholesteryl moiety of cholesterol esters. ${ }^{154}$ In contrast, in the structure of $\mathrm{HDL}_{s}$ the protein is associated, in its amphipathic helical regions, with the fatty acid chains of phospholipids and has no intrinsic affinity for cholesterol esters. ${ }^{155}$ It is of interest that the carotenoid content of lipoprotein fractions of Ajaia ajaja plasma follows that of cholesterol. ${ }^{18}$ The lipovitellins are 

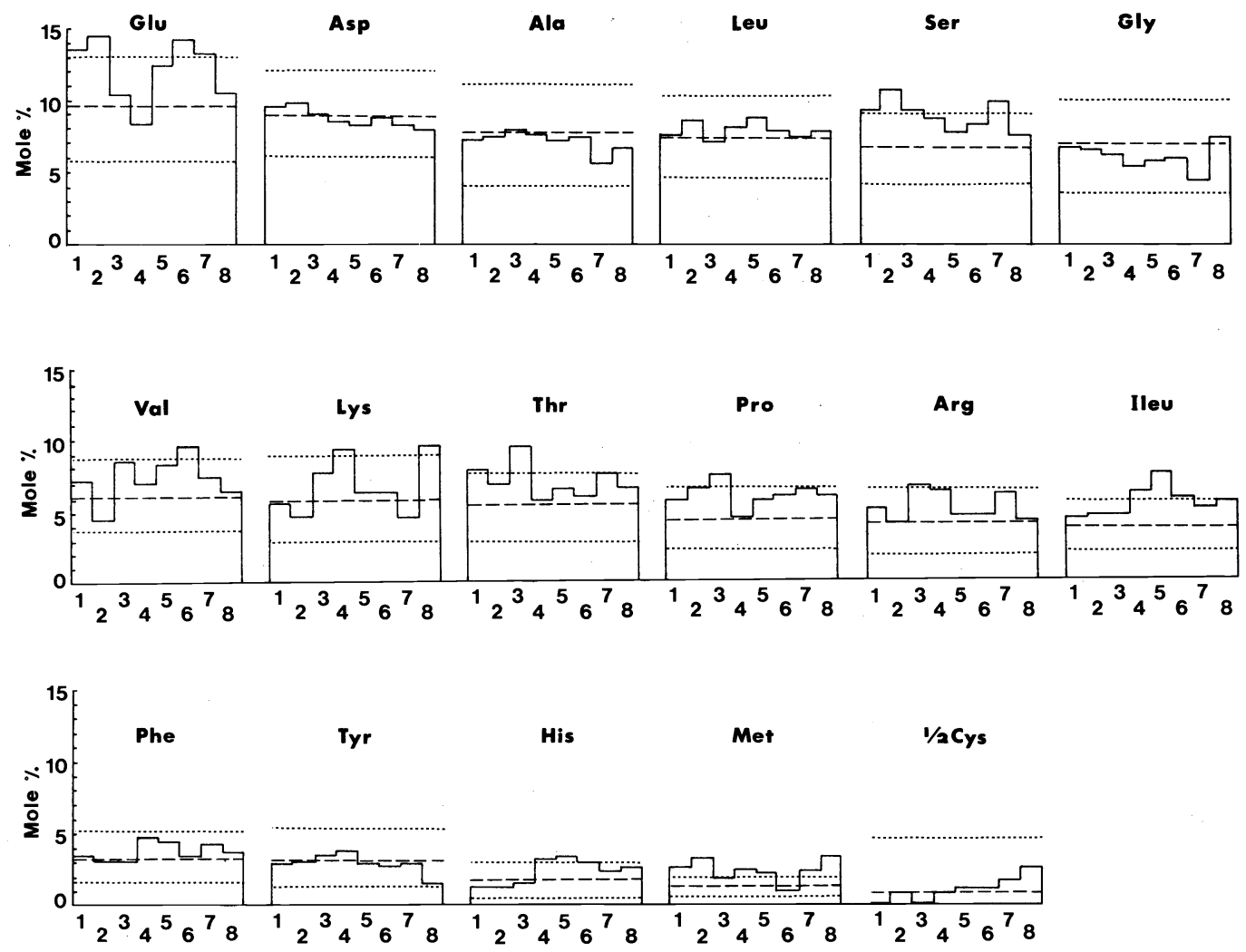

Fig. 1. Histogram showing the contents (mol\%) of amino acids of crustacean lipovitellins: (1) Homarus gammarus (L) ${ }^{56}$ (2) Cancer pagurus ; ${ }^{56}$ (3) Plesionika edwardsi ; $;$ (4) Procambarus sp. ${ }^{27}$ (5) Pagurus bernhardus ; ${ }^{51}$ (6) Pagurus prideauxi ; $;^{51}$ (7) Lepas sp.; ${ }^{31}$ (8) Branchipus stagnalis (L.) ${ }^{25}$ The contents of amino acids of the 'average protein'93 with their standard deviation of occurence àre given by the dashed and dotted horizontal lines, respectively.

Table 1. Comparison of compositions (mol \%) of lipovitellins, and some other proteins, in terms of amino acid sets

\begin{tabular}{|c|c|c|c|c|c|}
\hline & Amino acid se & & & & \\
\hline Proteins & $\underset{(\mathrm{mol} \%)}{\text { Apolar residues }(\mathrm{A}) \dagger}$ & $\begin{array}{l}\text { Polarity index }(\mathrm{P}) \ddagger \\
\quad(\mathrm{mol} \%)\end{array}$ & $\begin{array}{l}\mathrm{P} / \mathrm{A} \\
\text { ratio }\end{array}$ & $\begin{array}{l}\text { Small§ } \\
(\mathrm{mol} \%)\end{array}$ & $\begin{array}{l}\text { Charged } \uparrow \\
\text { (mol\%) }\end{array}$ \\
\hline Crustacean lipovitellin & & & & & \\
\hline Homarus gammarus & 25.1 & 52.3 & 2.1 & 13.9 & 33.9 \\
\hline Cancer pagurus & 23.6 & 52.0 & 2.2 & 13.9 & 33.0 \\
\hline Plesionika edwardsi & 25.2 & 54.5 & 2.2 & 13.9 & 34.3 \\
\hline Procambarus sp. & 24.1 & 49.8 & 2.1 & 12.8 & 32.1 \\
\hline Lepas $\mathrm{sp}$. & 26.6 & 52.1 & 2.0 & 10.1 & 32.3 \\
\hline Pagurus bernhardus & 30.0 & 47.2 & 1.6 & 12.8 & 31.3 \\
\hline Pagurus prideauxi & 27.3 & 49.8 & 1.8 & 13.1 & 33.5 \\
\hline Branchipus stagnalis & 26.9 & 48.8 & 1.8 & 13.9 & 32.2 \\
\hline Lamellibranch lipovitellin ${ }^{56}$ & 21.8 & 51.1 & 2.3 & 16.9 & 31.1 \\
\hline Insect lipovitellin ${ }^{50}$ & 26.6 & 55.1 & 2.1 & 8.5 & 38.8 \\
\hline Amphibian lipovitellin ${ }^{53}$ & 29.5 & 47.4 & 1.6 & 13.4 & 31.4 \\
\hline Avian lipovitellin $(\alpha)^{53}$ & 28.4 & 45.2 & 1.6 & 13.2 & 31.1 \\
\hline Ovorubin, Pomacea canaliculata ${ }^{56}$ & 28.9 & 49.5 & 1.7 & 11.8 & 34.3 \\
\hline $\begin{array}{l}\text { Serum low density (LDL) lipoprotein" } \\
\text { (human) }\end{array}$ & 283 & 514 & 18 & 116 & 328 \\
\hline Serum high density (HDL) lipoprotein $\dagger \dagger$ & & & & & \\
\hline (human) & 24.7 & 53.7 & 2.2 & 12.4 & 40.5 \\
\hline Lipoxygenase (pea, Pisum sativum L.) & 26.2 & 49.5 & 1.9 & 12.5 & 33.6 \\
\hline
\end{tabular}

$\dagger$ Apolar residues: $:^{95}$ Val, Ileu, Leu, Phe, Met.

$\ddagger$ Polarity index: $:^{4}$ Sum of mol\% values of Asp, Thr, Ser, Glu, Lys, His, Arg.

§Small amino acids:95 Ala, Gly

ๆCharged amino acids: ${ }^{95}$ Asp, Glu, Arg, Lys.

"Average amino acid composition derived from the values given in Refs. 52 and 55.

$\dagger \dagger$ Average amino acid composition derived from the values given in Ref. 54. 
Table 2. Estimation of relatedness of egg storage proteins (lipovitellins), serum lipoproteins and other proteins ( $\mathrm{S} \Delta \phi$ values are given in this table). Possibly related proteins are in italic

\begin{tabular}{|c|c|c|c|c|c|c|c|c|c|c|c|c|c|c|c|c|c|}
\hline 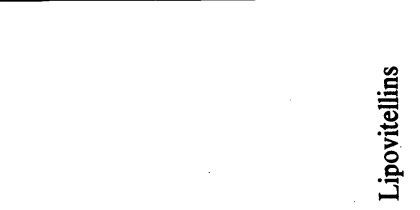 & 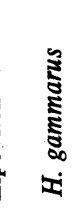 & 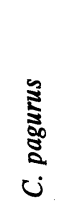 & 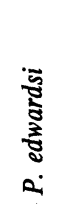 & 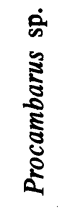 & م. & 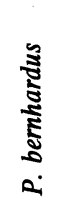 & 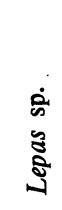 & 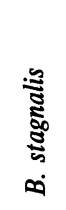 & 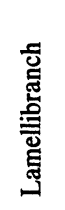 & 喜 & 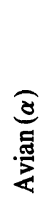 & $\begin{array}{l}\overrightarrow{\mathrm{E}} \\
\text { E. } \\
.\end{array}$ & 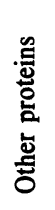 & 咅 & 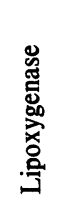 & $\overrightarrow{\mathrm{Q}}$ & 宣 \\
\hline \multicolumn{18}{|l|}{ Crustacean lipovitellin } \\
\hline H. gammarus & 0 & 16 & 20 & 59 & 20 & 24 & 18 & 44 & 36 & 40 & 36 & 70 & & 27 & 55 & 43 & 112 \\
\hline C. pagurus & 16 & 0 & 56 & 94 & 49 & 49 & 29 & 66 & 65 & 61 & 63 & 88 & & 50 & 68 & 48 & 115 \\
\hline P.edwardsi & 20 & 56 & 0 & 47 & 37 & 40 & 33 & 45 & 26 & 51 & 49 & 90 & & 45 & 71 & 78 & 155 \\
\hline Procambarus sp. & 59 & 94 & 47 & 0 & 64 & 39 & 54 & 29 & 68 & 19 & 24 & 77 & & 51 & 53 & 55 & 169 \\
\hline P. prideauxi & 20 & 49 & 37 & 64 & 0 & 10 & 29 & 51 & 72 & 36 & 31 & 84 & & 29 & 66 & 51 & 104 \\
\hline P. bernhardus & 24 & 49 & 40 & 39 & 10 & 0 & 27 & 35 & 66 & 20 & 16 & 77 & & 25 & 47 & 38 & 121 \\
\hline Lepas sp. & 18 & 29 & 33 & 62 & 29 & 27 & 0 & 54 & 57 & 44 & 39 & 79 & & 42 & 75 & 60 & 135 \\
\hline B. stagnalis & 44 & 66 & 45 & 30 & 51 & 35 & 62 & 0 & 60 & 28 & 32 & 107 & & 36 & 57 & 51 & 140 \\
\hline Lamellibranch lipovitellin & 36 & 65 & 26 & 68 & 72 & 66 & 57 & 60 & 0 & 40 & 40 & 118 & & 62 & 74 & 102 & 127 \\
\hline Amphibian lipovitellin & 40 & 61 & 51 & 19 & 36 & 20 & 44 & 28 & 40 & 0 & 6 & 71 & & 29 & 47 & 44 & 120 \\
\hline Avian lipovitellin $(\alpha)$ & 36 & 63 & 49 & 24 & 31 & 16 & 39 & 32 & 40 & 6 & 0 & 75 & & 32 & 46 & 50 & 116 \\
\hline Insect lipovitellin & 70 & 88 & 90 & 77 & 84 & 77 & 79 & 107 & 118 & 71 & 75 & 0 & & 33 & 48 & 55 & 108 \\
\hline Ovorubin, $P$. canaliculata & 27 & 50 & 45 & 51 & 29 & 25 & 42 & 36 & 62 & 29 & 32 & 33 & & 0 & 23 & 31 & 125 \\
\hline \multirow{3}{*}{$\begin{array}{l}\text { Serum low density (LDL) lipoprotein } \\
\text { (human) } \\
\text { Serum high density (HDL) lipoprotein } \\
\text { (human) }\end{array}$} & ..) 55 & 68 & 71 & 53 & 66 & 47 & 75 & 57 & 74 & 47 & 46 & 48 & & 23 & 0 & 30 & 127 \\
\hline & 43 & 48 & 78 & 55 & 51 & 38 & 60 & 51 & 102 & 44 & 50 & 55 & & 31 & 30 & 0 & 88 \\
\hline & ${ }^{n}{ }_{112}$ & 115 & 155 & 169 & 104 & 121 & 135 & 140 & 127 & 120 & 116 & 108 & & 125 & 127 & 88 & 0 \\
\hline
\end{tabular}

also closely related in amino acid composition to the storage glycoprotein, ovorubin ${ }^{56}$ (Table 2).

The carotenoid-lipoglycoproteins (female-specific proteins) that accumulate in the blood of certain Crustacea during vitellogenesis have been shown, in some instances, to be electrophoretically identical with (Paratelphusa hydrodomous ${ }^{59}$ ), related to $\left(E\right.$. analog $\left.a^{17}\right)$, or both electrophretically and immunologically indistinguishable from (Callinectes sapidus $;^{60}$ Orchestia gammarella $;^{61}$ Procambarus spp. ${ }^{27}$ ) the lipovitellin deposited in the ovary and eggs.

The synthesis and deposition of crustacean lipovitellin is under endocrine control, but the site of synthesis, probably external to the oocyte in some species, is still controversial. ${ }^{27,41,59-61}$ The breakdown of lipovitellin during embryonic development has been followed electrophoretically and immunologically. ${ }^{46,61}$ The protein and lipid are utilised to satisfy growth and energy requirements ${ }^{1,20,61}$ while the carotenoid becomes concentrated in the naupliar eye and chromatophores. ${ }^{6,9,15,20,29,62}$ Opinions differ as to whether the carotenoid content of the egg changes during development, ${ }^{17,20,39,46}$ although it may be altered chemically. ${ }^{20}$

The lipovitellin is either dispersed in the oocytes of Crustacea (e.g. within spheroid micelles, Lepas $\mathrm{sp}^{29}$ ) or in granular yolk bodies. ${ }^{63}$ In eggs of the anostracans, $A$. salin $^{24}$ and $B$. stagnalis, ${ }^{25}$ however, the canthaxanthinlipovitellin complex is packaged into small, oval platelets together with large amounts of diguanosine nucleotides and some deoxyribonucleic acid. The nucleotides are utilised for purine synthesis during development. ${ }^{64,65}$

In some Crustacea, carotenoid-lipoglycoproteins (e.g. the green complexes of certain anostracans ${ }^{33}$ ) occur in the blood of males and females. These pigments, not yet fully characterised, may have a function in colour adaptation. ${ }^{66}$ However, purple and green carotenoid-lipoprotein complexes are seen in the blood of Tanymastix lacunae in separate individuals (male or female) at the same stage of growth and in the same culture medium. ${ }^{32}$ A function other than that of protective coloration may therefore be fulfilled by these complexes. In another species (Branchinecta packardi) carotenoid is mainly present, in the female only, as blue needle-like deposits (carotenoidprotein or lipoprotein complex?). ${ }^{32}$

Cuticular, epidermal and other carotenoidlipoglycoproteins

The green cuticular and epidermal pigments of several idoteid isopods have been identified as lipoglycoproteins containing, in addition to canthaxanthin, several lipidassociated carotenoids. ${ }^{34-36}$ While detailed chemical analyses have not been attempted, the protective coloration function of these pigments has been convincingly presented. $^{35,67}$

The chemical composition of the blue epidermal pigment of Palaemon serratus, the synthesis of which is under hormonal control, ${ }^{68}$ has not been reported.

The blue muscle pigment of the sea squirt, Salpa cylindrica, is unusual in having a single-banded absorption spectrum derived from a carotenoid with a typical triple-peaked spectrum. ${ }^{21}$ Composition of the protein has not been determined; the unidentified carotenoid fails to combine with the apoproteins of several simple carotenoproteins (Table 5).

\section{Enzymes}

Enzyme utilising carotenoids as substrates must necessarily occur as "carotenoid-protein complexes". 2,69 With the exception of lipoxygenase of pea (Pisum sativum L.) ${ }^{70}$ compositions of carotenoid-metabolising enzymes have yet to be reported. The lipoxygenase which oxidises $\beta$-carotene in the presence of linoleic acid and $\mathrm{O}_{2}$, has an amino acid composition consistent with that of soluble lipoproteins (Tables 1 and 2), with which it may be provisionally classed. 


\section{CAROTENOPROTEINS}

There is a clear distinction between the carotenoidlipoprotein complexes and those associations in which the carotenoid is bound stoichiometrically to a simple protein or, in a single known instance (ovorubin), to a glycoprotein. ${ }^{1}$ True carotenoproteins, typified by ovorubin and crustacyanin, the blue pigment of lobster carapace, are stable combinations where the carotenoid tends to stabilise the tertiary and/or quaternary protein structures, a property well known for other polyenes in combination with protein. ${ }^{87,89}$ Native carotenoprotein may often be reconstituted from carotenoid and freshly prepared apoprotein. ${ }^{1}$

\section{Physical properties and subunit structure}

Simple carotenoproteins have been isolated from several invertebrate species and a variety of tissues (Fig. 2). The prosthetic group has been identified invariably as astaxanthin. The position of the absorption maxima of the blue/purple combinations range from $520 \mathrm{~nm}$ (carapace carotenoprotein of Pachygrapsus marmoratus) $)^{71}$ to $655 \mathrm{~nm}$ (carapace pigment of Cambarus clarkii) $?^{75}$

Molecular weights of carotenoproteins (native or $\alpha$-forms) range from $5 \times 10^{4}$ (carapace carotenprotein of Aristeus antennatus) to $1 \times 10^{6}$ (asymmetrical mandible carotenoprotein of A. antennatus) ${ }^{71}$ At low ionic strength many of the proteins dissociate to give purple derivatives, $\beta$-forms, of molecular weight $4.0-5.0 \times 10^{4}$. The apoproteins, prepared simply by acetone precipitation, are often electrophoretically heterogeneous. Their molecular weights, lying between 1.8 and $2.6 \times 10^{4}$ (crustacyanin; ${ }^{77-81}$ mantle carotenoprotein of Velella sp., ${ }^{31} A$. antennatus carotenoproteins; ${ }^{71}$ hypodermal carotenoproteins of Labidocera acutifrons ${ }^{72}$ and Anomalocera patersoni ${ }^{31}$ ) or between 0.8 and $1.0 \times 10^{4}$ (carapace carotenoprotein of $C$. clarkii $^{73}$ and hypodermal carotenoprotein of Labidocera sp. ${ }^{31}$ ), indicate the influence of the prosthetic group on quaternary structure. Each apoprotein may bind one (crustacyanin; $;^{78,79,88}$ ovorubin; $;^{51}$ A. antennatus carotenoproteins $^{71}$ ), two (Velella sp. and Anomalocera patersoni carotenoproteins ${ }^{31}$ ) or, possibly, three (Labidocera acutifrons carotenoprotein ${ }^{72}$ ) molecules of astaxanthin. Exceptionally, the apoprotein of ovorubin retains the quaternary structure of the carotenoprotein. ${ }^{51}$

A yellow complex isolated from lobster carapace ${ }^{79-81}$ has a low minimum molecular weight (based on astaxanthin content) of $4.4 \times 10^{3}$ and an absorption maximum at $409 \mathrm{~nm}$, well below that of carotenoid in hexane. ${ }^{79}$ The characteristics of the absorption spectrum (half-band width, oscillator strength and extinction coefficient) are quite different from those of the blue/purple carotenoproteins. It has similar absorption and optical rotatory dispersion (ORD) spectra to those of astaxanthin aggregates in which the molecules are believed to be stacked with the dipoles of successive molecules at an angle to one another. ${ }^{79,82}$ It is in doubt whether this carotenoid aggregate, kept in solution by a protein component immunologically related to crustacyanin, ${ }^{79,82}$ occurs naturally in the carapace.

The five apoprotein units of crustacyanin have been obtained in homogeneous state by ion-exchange chromatography. ${ }^{83}$ The two components which migrate the furthest anodically in starch gel electrophresis at $\mathrm{pH}$ 8.6 , show similar sizes $\left(1.8-2.0 \times 10^{4}\right)$ in gel filtration ${ }^{83}$ and
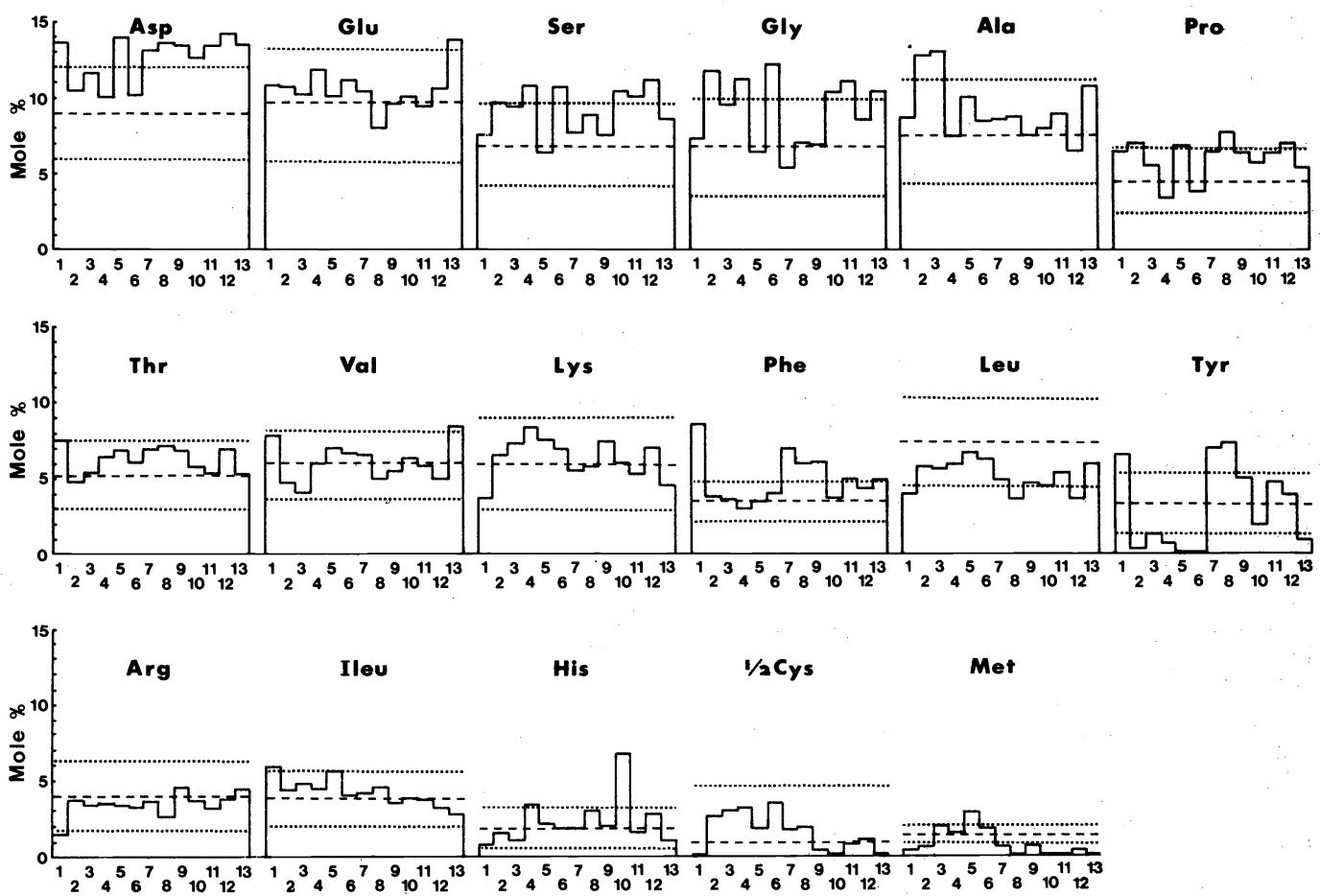

Fig. 2. Histogram showing the contents ( $\mathrm{mol} \%$ ) of amino acids of carotenoproteins: (1) Cambarus clarkii carapace; ${ }^{73}$ (2) Labidocera sp., hypodermis; ${ }^{31}$ (3) Anomalocera patersoni, hypodermis; ${ }^{31}$ (4) Porpita sp., mantle and tentacles; ${ }^{31}$ (5) Labidocera acutifrons, hypodermis; ${ }^{72}$ (6) Velella sp., mantle; ${ }^{31}$ (7) Homarus gammarus (L.), carapace, average value $;^{71,78,79}$ (8) Clibanarius erythropus, exoskeleton:;1 (9) Scyllarus arctus, carapace; ${ }^{71}$ (10) Aristeus antennatus, mandibles; ${ }^{71}$ (11) Aristeus antennatus, carapace; ${ }^{7 \mathrm{r}}$ (12) Aristeus antennatus, stomach; ${ }^{71}$ (13) Eriphia spinifrons, carapace. ${ }^{71}$ The content of amino acids of the 'average protein ${ }^{93}$ with their standard deviation of occurrence are given by the dashed and dotted horizontal lines, respectively. 
acrylamide-sodium dodecylsulphate electrophoresis. ${ }^{51}$ The amino acid compositions differ by only $4 S \Delta \phi$ units, ${ }^{83}$ a value obtainable for identical proteins. ${ }^{57}$ The three remaining apoportein units, two migrating cathodically and one anodically, are also similar to each other in size $\left(2.1-2.3 \times 10^{4}\right)$ and amino acid composition, pairs giving $S \Delta \phi$ values of 8,9 and $23 .^{83}$

The two sets of subunits are themselves related in composition, for the major components of each set differ by only $46 S \Delta \phi$ units, most of which is due to differences in leucine and threonine. ${ }^{83}$ The amino acid compositions of $\alpha$ and $\gamma$-crustacyanin are consistent with an equal contribution of each set of subunits to the structures. ${ }^{83}$ The latter protein has a higher sedimentation and diffusion constant than $\alpha$-crustacyanin and elutes before it in gel filtration. It differs in shape and absorption maximum from $\alpha$-crustacyanin, but has an identical amino acid composition, molecular weight and subunit structure. ${ }^{79,83}$ All five apoproteins retain the ability to recombine with astaxanthin, singly or in pairs, to form the noninterconvertible dimeric $\beta$-crustacyanins. The preferred association is between subunits of the two separate types; these forms of $\beta$-crustacyanin are found on irreversible dissociation of $\alpha$-crustacyanin at low ionic strength. ${ }^{83}$ Whether the carotenoid acts as a direct cross-link between apoproteins, as suggested for the binding of FAD in glucose oxidase ${ }^{85}$ and NAD in lactate dehydrogenase, ${ }^{86}$ whether it changes the configurations of the apoproteins into those suitable for dimerisation, as for retinol in the binding of retinol-binding protein to prealbumin, ${ }^{87}$ or whether it acts as a hydrophobic-Van der Waals bridge, is a matter of conjecture and will be discussed later. Apoproteins of pigments prepared from stored material can no longer give the $\alpha$-form of the proteins on recombination with astaxanthin (e.g. for crustacyanin and A. antennatus carotenoprotein, Table 5). Prolonged storage similarly inhibits regeneration of the visual pigment, rhodopsin. ${ }^{88}$

The physical properties of crustacyanin and its derivatives have recently been reviewed. ${ }^{89}$

\section{Compositions}

The amino acid compositions of thirteen blue/purple carotenoproteins from diverse tissues of copepod and decapod Crustacea and from two siphonophore species are known. These are listed in a histogram (Fig. 2) in order, from left to right, of decreasing wavelength of absorption maxima. There is no apparent relationship between the content of any particular amino acid or group of amino acids and the position of the absorption maximum of the pigments, except possibly for isoleucine which tends to lower values with decreasing wavelength maximum.

As the size of the carotenoid ( $c a .28 \times 5 \AA$ ) is comparable with the diameter of the apoprotein ( $c a .40 \AA$ or less), ${ }^{71-73}$ a large part of the protein may be expected to be involved in its binding. If the binding sites are of an unusual nature, these could influence the overall composition. An indication that this may be the case is found when $S \Delta \phi$ values for pairs of the carotenoproteins are inspected (Table 3 ). The proteins, from different species and tissue environments, are evidently related in composition. In Fig. 2 the amino acid compsoition of the "average protein"93 is given, with the standard error of occurrence of each amino acid as a criterion for comparison. The carotenoproteins are characterised by high contents of acidic (mainly amidated) amino acids, particularly of aspartic acid. The consistently low contents of leucine and high content of serine, threonine and proline may have some relevance, discussed later, to the binding of carotenoid. The carotenoproteins have a low content of amino acids (glycine and alanine), reflected in the low (anhydrous) mean residue weights. The hydrophobicity values are not particularly high, while the values of the polarity index are similar to those for the soluble proteins and lipoproteins ${ }^{94}$ (Table 4).

The copepod and siphonophore carotenoproteins contrast with those of decapods in having fewer aromatic amino acids. In some species tyrosine is either completely absent or present in uncommonly small amounts (Fig. 2). The species investigated inhabit the top few centimetres of the sea surface in tropical waters and are thus exposed to the sun's u.v. radiation. The sensitivity of rhodopsin to bleaching by u.v. light ${ }^{90}$ emphasis the possible (cf. 130) advantage to a stable carotenoprotein of a low content of aromatic amino acids. The carotenoprotein of Velella also has a high content of cysteine, partly in sulphydryl form. ${ }^{31}$

\section{Specificity of the combinations}

Examination of the specificity of carotenoid attachment to apocrustacyanin has shown that to effect changes in quaternary structure, the carotenoid must have 4- and $4^{\prime}$-keto groups. ${ }^{82,83,91}$ The ability of a range of synthetic and natural carotenoids to bind specifically to apoproteins derived from carotenoproteins of different species has confirmed the earlier conclusion for crustacyanin ${ }^{91}$ and extended the studies (Table 5).

(a) Crustacyanin. The presence of keto groups in both the 4- and 4'-position of the $\beta$-ionone rings (or equivalent positions in the cyclopentene analogues) of the carotenoid is necessary to bring about changes in the structure of the apoprotein, with the formation of $\beta$-crustacyanin.

Carotenoids with a 4-keto group in only one $\beta$-ionone or cyclopentene ring $\left(\beta, \beta\right.$-carotene-3,4-dione; $3,3^{\prime}, 4^{\prime}$ trihydroxy- $\beta, \beta$-caroten-4-one (idoxanthin); $4^{\prime}$-hydroxy$\beta, \beta$-caroten-4-one; 2 -nor $\beta$-carotene, $\beta$-carotene-3,4dione) show a low affinity for the apoprotein, and apparently fail to bind with sufficient specificity to bring about the configurational changes in the protein necessary for dimerisation. $\beta, \beta$-caroten-4-one (echinenone) does not bind to the protein in demonstrable amounts.

Whether the polyenes have planar cyclopentene ${ }^{92}$ rings, twisted (relative to the plane of the polyene) $\beta$-ionone ${ }^{92}$ rings, or a mixture of the two, evidently has no influence on the ability to confer a quaternary structure upon apocrustacyanin. Similar observations have been made with opsin. ${ }^{98}$ The absorption bands of the cyclopentene carotenoid-proteins lie at longer wavelengths than those of $\beta$-ionone derivatives. Carotenoids with both cyclopentene and $\beta$-ionone rings give pigments with two absorption bands, one of which is bathochromically shifted in relation to the spectrum of free carotenoid.

Recombinations obtained with canthaxanthin, astacene and astaxanthin-3,3'-dimethylether show that enolisation of the 4- and $4^{\prime}$-positions is unnecessary and that the 3and $3^{\prime}$-hydroxyl groups are dispensible for satisfactory recombination. Steric factors or methodology may be responsible for the lack of reconstitution found with astaxanthin diacetate and dipalmitate. Crustaxanthin, in which the shape of both $\beta$-ionone rings is altered ${ }^{79}$ as compared with astaxanthin, has negligible affinity for the protein; idoxanthin, where the shape of one ring is altered, gives exclusively an apo-sized recombination product, (cf. also 79). 


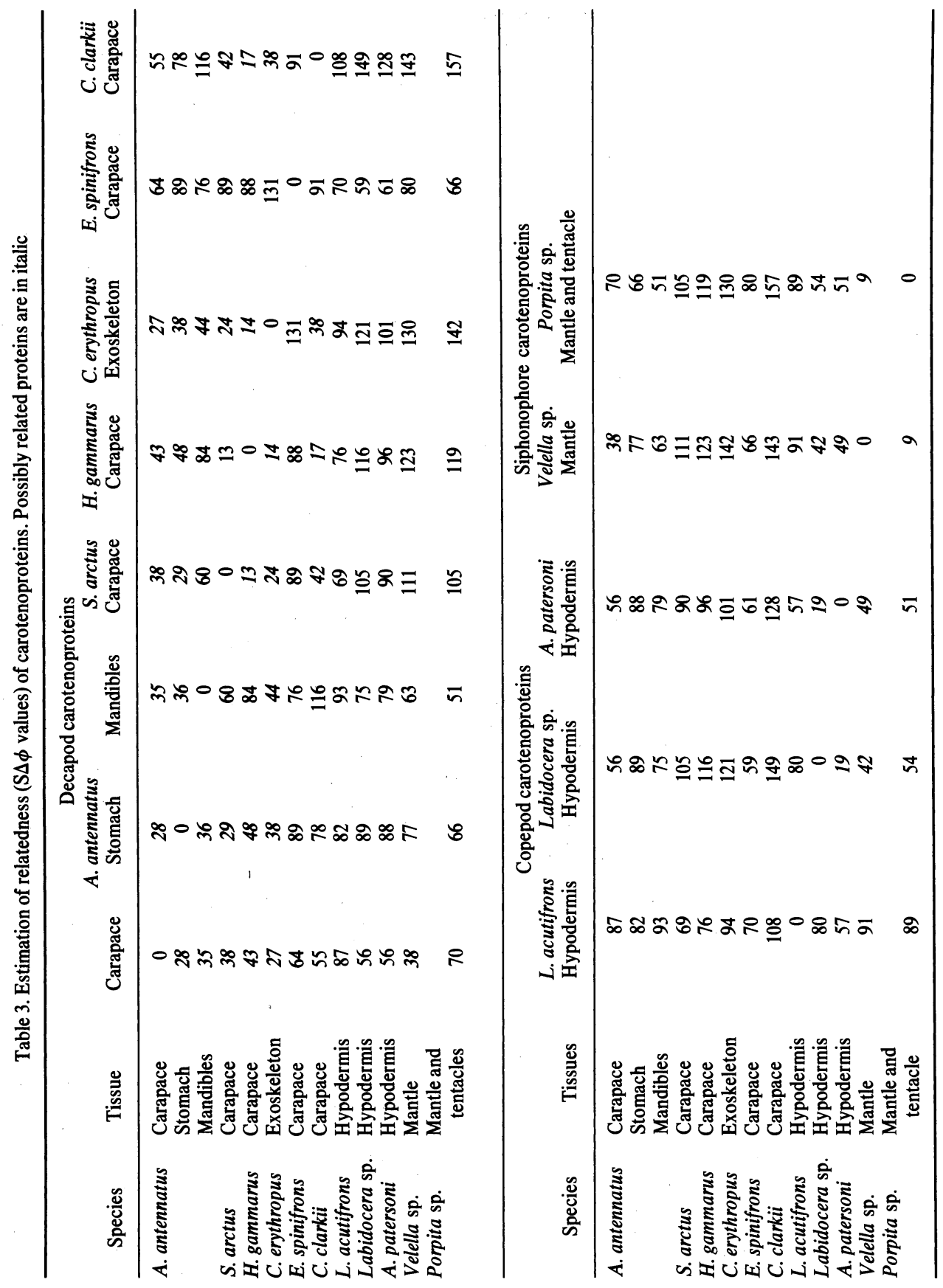


Table 4. Comparison of compositions (mol\%) of carotenoproteins and different groups of soluble protein, in terms of amino acid sets. Average hydrophobicity and mean (anhydrous) residue weight of carotenoproteins

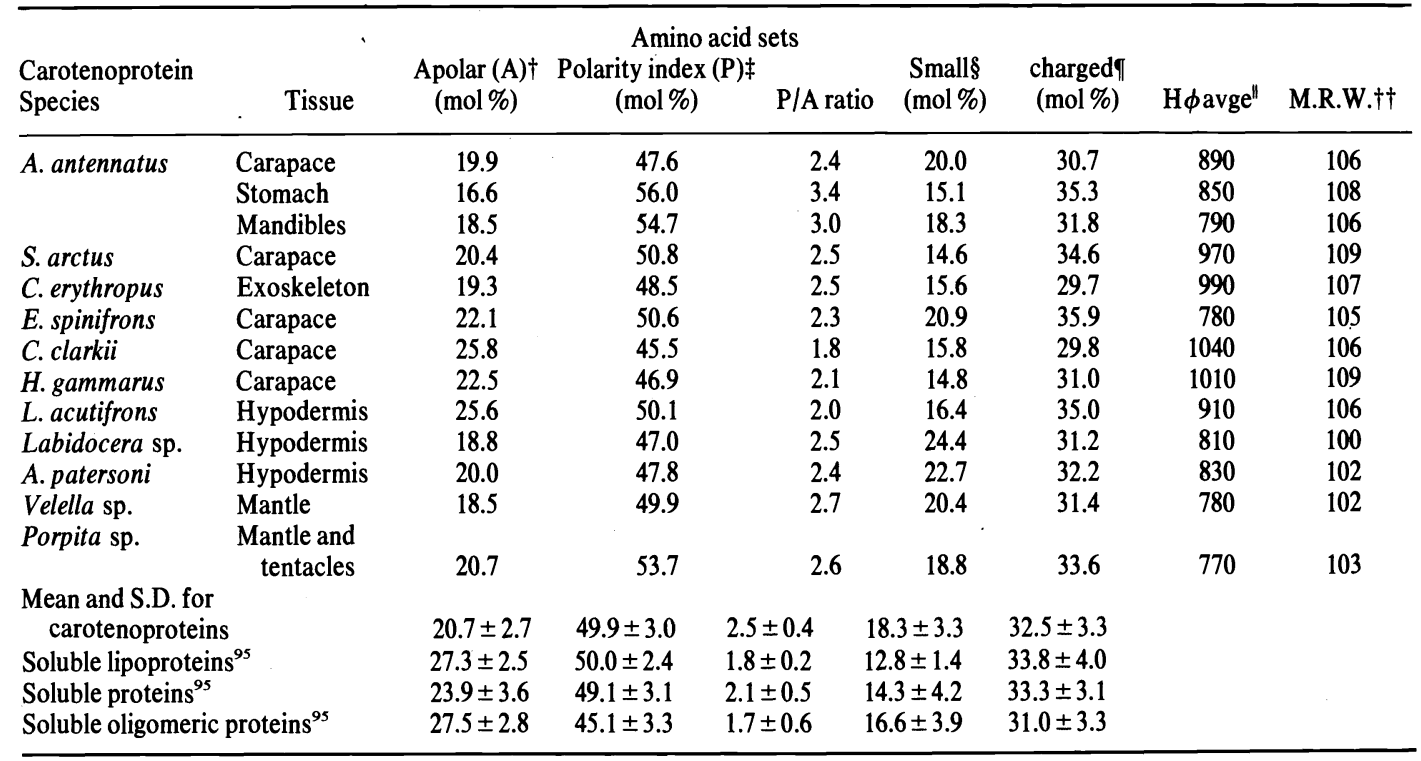

†Apolar residues: ${ }^{95} \mathrm{Val}$, Ileu, Leu, Phe, Met.

$\ddagger$ Polarity index: $:^{94}$ Sum of mol\% values of Asp, Thr, Ser, Glu, Lys, His, Arg.

$\S$ Small amino acids: $:^{95}$ Ala, Gly.

ๆCharged amino acids: ${ }^{95}$ Asp, Glu, Arg, Lys.

"Average hydrophobicity, cals/residues, calculated from hydrophobicity values given in Ref. 96 and corrected values Ref. 97.

$\dagger \dagger$ Mean (anhydrous) residue weight.

Acetylenic carotenoids, in which the distance between 4 - and $4^{\prime}$-keto groups in the $\beta$-ionone or cyclopentene rings is shortened, ${ }^{83}$ are capable, with the exception of dehydrocanthaxanthin, of associating the apoprotein units. Mono- and di-acetylenic ( 7,8 and/or $7^{\prime}, 8^{\prime}$ positions) carotenoids, pectenoxanthin and pectenolone, occur naturally in the carotenoid-lipoglycoprotein of Pecten maximus. ${ }^{16}$ Acetylenic $\left(7^{\prime}, 8\right.$ and $/$ or $7^{\prime}, 8^{\prime}$ positions) derivatives of astaxanthin are found in the blue carotenoidprotein complex of unknown nature, isolated from the skin of Asterias rubens. ${ }^{99}$

The shortened carotenoid 15,15'-dehydro- $8^{\prime}$-apo- $\beta$ carotene-8' al-3, 4-dione ( $\beta$-apocarotenal) binds to apocrustacyanin without bringing about association of the subunits. Retinals with shortened chains do not form visual pigments ${ }^{100}$ or bind to retinol-binding protein of human plasma. ${ }^{101}$

The specificity of the carotenoid-protein association in another decapod carotenoprotein, that of the stomach wall of A. antennatus, resembles that in crustacyanin. Carotenoids that have a 4-keto group in one of the $\beta$-ionone rings can in some cases (e.g. idoxanthin), however, bring about dimerisation of the apoprotein units. The second $\beta$-ionone ring may evidently be accommodated at its binding site even without a 4-keto substituent, provided that there is strong attachment of the first ring. It may be supposed that firm binding of just one $\beta$-ionone ring may be sufficient to alter the tertiary, and hence quaternary, structure of the apoprotein. These results imply that the carotenoid does not act as a direct cross-link between the apoproteins. Preliminary recombination studies for the hypodermal pigment of the copepod A. patersoni suggests similar specificity.

(b) Velella mantle carotenoprotein. Conflicting reports on the position of the absorption maxima of Velella and
Porpita carotenoproteins were attributed previously to a dependence of the carotenoid-protein association on ionic strength and temperature. ${ }^{102}$ The presence of specific halide-ion binding sites, which influence the carotenoidprotein interaction, may now be considered as the explanation for the observed variability of the absorption spectra. These sites have been investigated in some detail for the Velella carotenoprotein and are the subject of a forthcoming paper. ${ }^{31}$ Briefly, the native carotenoprotein, with absorption maximum at $630 \mathrm{~nm}$, alters on storage in the absence of halide ions to give proteins differing in size, with absorption maxima at $620 \mathrm{~nm}$ and $600 \mathrm{~nm}$ (in the presence of halide ions). The latter protein, of molecular weight $c a .380,000$, was used for the recombination studies. On removal of halide ions this protein, reversibly, both dissociates to purple $\beta$-sized units $\left(\lambda_{\max }\right.$ $570 \mathrm{~nm}$ ) and alters in configuration to give a derivative with a hypsochromically shifted absorption spectrum $\left(\lambda_{\max } 583 \mathrm{~nm}\right)$ but of unaltered molecular size. The ion-binding sites, three per apoprotein unit, have high (temperature dependent) association constants for the halide ion and probably consist of clusters of basic (arginine and lysine) residues. The spectra for the reconstituted pigments (Table 5) are given in the presence and absence of saturating concentrations of chloride ions.

The allowable alterations in the structure of the carotenoid for pigment formation are similar for both the siphonophore pigment and crustacyanin. The carotenoid derivatives have different effects on the quaternary structures of the two apoproteins. Carotenoids with a 4-keto group in one ring ( $\beta$-apocarotenal; $4^{\prime}$-hydroxy- $\beta, \beta$ caroten-4-one; idoxanthin; $\beta, \beta$-carotene-3, 4-dione), but not echinenone, bring about dimerisation of the Velella apoprotein. The Velella protein resembles, with exceptions (e.g. $4^{\prime}$-hydroxy- $\beta, \beta$-caroten-4-one; $\beta, \beta$-carotene- 
3,4-dione), the $A$. antennatus pigment in this respect. $\beta$-Forms of the protein may be obtained when 4-keto groups are present on both rings (e.g. canthaxanthin and astaxanthin diacetate, but not astacene diacetate). Further polymerisation of the protein occurs if the carotenoid has additional hydrophilic substituents (e.g. 2 -nor $\beta$-carotene, $\beta$-carotene-3,4,4'-trione; astacene; violoerythrin), even for acetylenic derivatives (e.g. dehydroastacene and dehydrovioloerythrin).

The Velella apoprotein has two carotenoid-, and so four $\beta$-ionone-, binding sites. ${ }^{31}$ One can evisage that the 4-monoketo carotenoids are bound so that the 4-keto- $\beta$ ionone groups occupy two sites on one face of the protein and provide the correct configuration along that face (only) for interaction with a similar complementary face of a second apoprotein unit; polymerisation cannot then proceed further than the $\beta$-form of the protein.

(c) Ovorubin. The length of the carotenoid, the size and shape of the $\beta$-ionone ring and the angle of the ring about the $6-7$ bond to the plane of the polyene chain can be altered without inhibiting binding of the carotenoid. Enolisation of the 4- and 4'-keto groups, or of the 3- and $3^{\prime}$-keto groups, is not required for carotenoid binding since $\beta$-apocarotenal, astaxanthin diacetate, violoerythrin and dehydrovioloerythrin can give pigments with apoovorubin. The binding nonetheless is fairly selective since canthaxanthin and 2 -nor $\beta$-carotene, $\beta$-carotene-3,4-dione have no affinity for the binding site, in contrast to $4^{\prime}$ hydroxy- $\beta, \beta$-caroten-4-one and $\beta, \beta$-carotene-3,4-dione.

The nature of the binding site, which alters the relative importance of excitations to different vibrational levels in the associated carotenoid giving rise to the fine structure seen in the spectrum, is unknown. Ovorubin can be dissociated with sodium dodecylsulphate and separated into two glycoprotein fractions with molecular sizes of about $2.2 \times 10^{4}$ and $3.5 \times 10^{4}$, respectively. The larger fraction recombines with astaxanthin to give the characteristic absorption spectrum of the original pigment. ${ }^{103}$

\section{Mode of binding}

It has been emphasised that in the spectrum of crustacyanin the extinction coefficient, half-band width and oscillator strength of astaxanthin are not significantly altered compared with that of the carotenoid dissolved in hexane. ${ }^{79}$ The same is true for the carotenoproteins listed in Table 6 and for some other carotenoproteins (cf. half-band width of Pontella fera ${ }^{14}$ and Cambarus clarkii $^{73}$ carotenoproteins and some decapod stomach carotenoproteins ${ }^{15}$ ). The invariability of the shape of the absorption spectra, in marked contrast to the alterations in the spectra of the bound carotenoid in carotenoidlipoglycoproteins, implies that a common binding mechanism exists for most carotenoproteins. It has been stressed that it is the over-all excitation energy of astaxanthin that is altered in crustacyanin, and that there is no large change in the nature of the electronic transition and relative importance of excitation to different vibrational levels. Polarisation of the carotenoid, charge transfer interaction and medium effects thus cannot explain the bathochromic shift in the absorption spectrum of the bound astaxanthin. ${ }^{79}$

In crustacyanin, and other carotenoproteins, astaxanthin is presumably bound non-covalently, since it is easily removed by organic solvents. No evidence has been obtained for labile Schiff's base formation between the keto groups of astaxanthin and amino groups of crustacyanin, or of linkages involving sulphydryl groups. ${ }^{79,81}$ A sugges- tion $^{72}$ that astaxanthin may be bound by unstable anhydride bonds to the carboxyl groups of aspartic acid has been disproved experimentally. Amidation of the carboxyl groups of apocrustacyanin does not eliminate the affinity of the protein for its prosthetic group. ${ }^{51}$ Non-covalent electrostatic attachment, originally suggested by Kuhn and Sörensen to account for the colour of ovoverdin, in which the bis-dianion of astaxanthin is bound to basic groups of the protein, is unlikely to be the mode of binding in crustacyanin both from spectroscopic evidence ${ }^{79}$ and from the ability of astacene, canthaxanthin and violoerythin to give coloured products with the apoprotein. Recently the astaxanthin removed from crustacyanin (and ovoverdin) has been shown to be optically active in the 3and $3^{\prime}$-position $\left(3 S, 3^{\prime} S\right)^{104}$ which is difficult to explain if it is bound as the tetra-anion. The low content of hydrophobic amino acids and the not unusual average hydrophobicity values for the carotenoproteins, would seem to make hydrophobic bonding, of the type suggested for retinol in retinol-binding protein, ${ }^{105-7}$ unlikely. In addition, studies in the effects of solvents on the spectrum of astaxanthin showing the insensitivity of the absorption band to the nature of the solvent, ${ }^{82}$ make it improbable that hydrophobic bonding alone could account for the large bathochromic shifts in the absorption bands of the pigments. The failure to show induced fluorescence of the carotenoid in crustacyanin upon excitation at $280 \mathrm{~nm},{ }^{79}$ in contrast to the results for retinol-binding protein, ${ }^{108}$ would indicate that aromatic amino acids are probably absent from the vicinity of the polyene. Exciton interaction between carotenoid molecules, aligned head to tail, on adjacent apoprotein units is an improbable reason for the spectral shifts of the bound carotenoid in carotenoproteins as it would alter the shape of the spectrum. ${ }^{79}$ It could, however, explain what appears to be a splitting in the absorption band in the spectrum of Labidocera sp. carotenoprotein (Table 6).

A model, based on chemical analogies, which satisfactorily accounts for the absorption spectra of blue and purple carotenoproteins, has been put forward by Buchwald and Jencks. ${ }^{79}$ It is proposed that the spectral characteristics of the crustacyanin pigments (and rhodop$\sin )^{79,109}$ are due to distortion of the polyene about the double bonds with a consequent decrease in double-bond order. For the mechanism to be valid, the methyl groups of the polyene chain must be immobilised and the $\beta$-ionone rings bound to the protein so as to be twisted out of the plane of the conjugated polyene, thereby localising the strain in the double, rather than single, bonds. The shape of the absorption band in the visible region should then be unaltered but bathochromically shifted by an amount depending on the degree of twist. The theory is consistent with the lack of demonstrable intermediates during the denaturation of crustacyanin, ${ }^{79}$ and for the more strongly bathochromically shifted absorption bands of analogous pigments formed from flat cyclopentene carotenoid derivatives (e.g. violoerythrin and dehydrovioloerythrin, Table 5). The more complex spectra of the mixed cyclopentene, $\beta$-ionone ring carotenoproteins may mean that in these combinations additional polarisation effects are superimposed on the twisting. In the case of rhodopsin, the binding is known to involve the protonated Schiff's base of the polyene; medium and counter-ion effects, as well as twisting of the chromophore, have been suggested as causes for the bathochromic shift in the absorption spectrum. ${ }^{110}$ The ability of 9,13-desmethylretinenal and other demethylated 


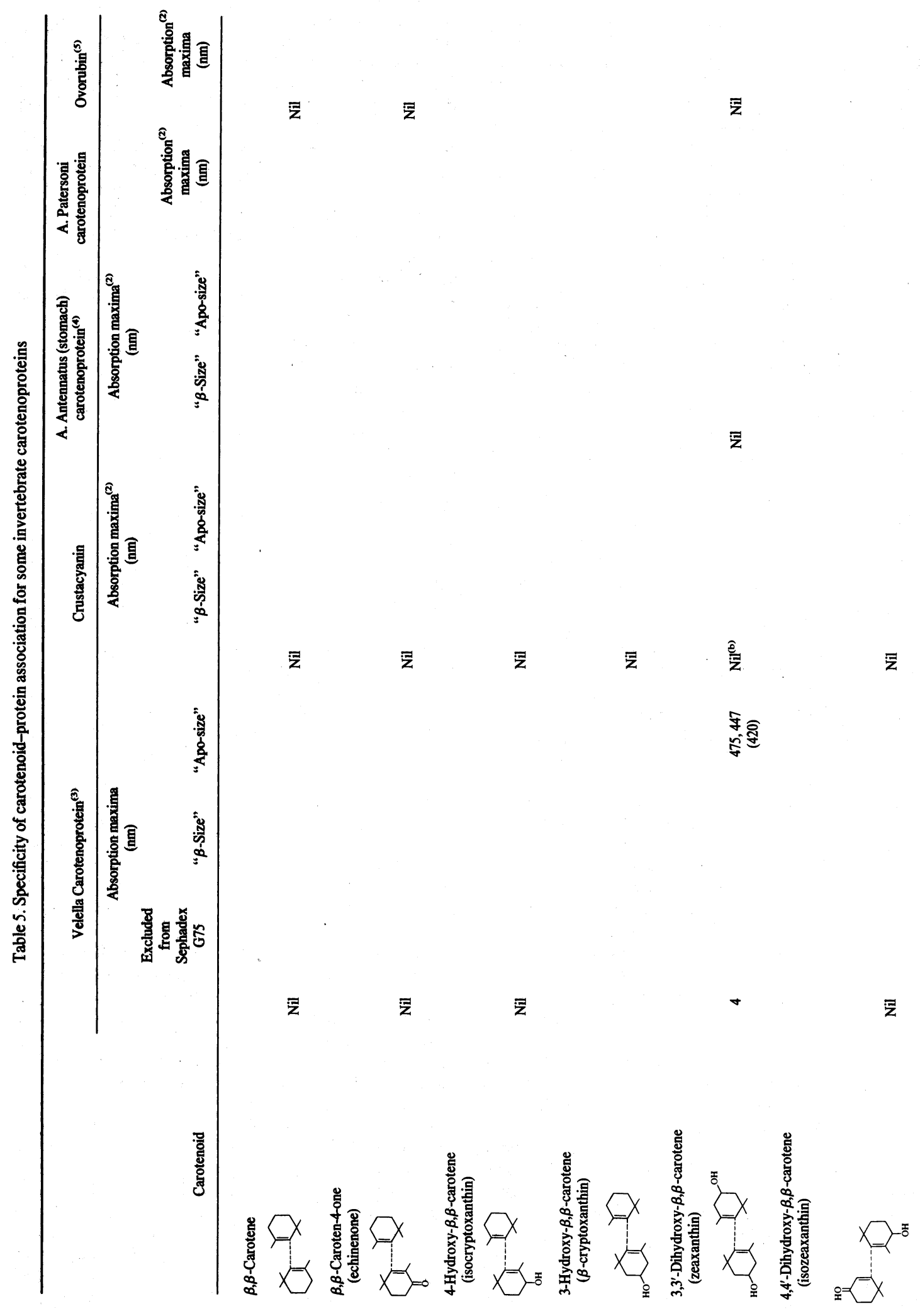




\begin{tabular}{|c|c|c|c|c|c|}
\hline$\%$ & 离 & 要 & & & 은 \\
\hline 9 & 0 & ల్ & $\overline{\mathbf{z}}$ & $\overline{\mathrm{z}}$ & \\
\hline 原 & 鸹 & $\sqrt{\bar{g}}$ & 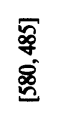 & 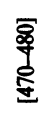 & 氮 \\
\hline 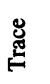 & 递 & 总 & + & 总 & + \\
\hline & & s & & 8 & \\
\hline
\end{tabular}

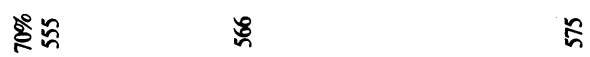

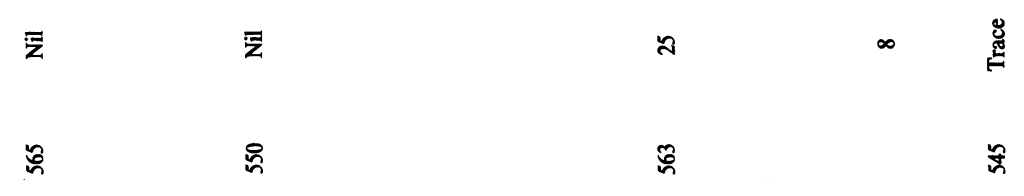

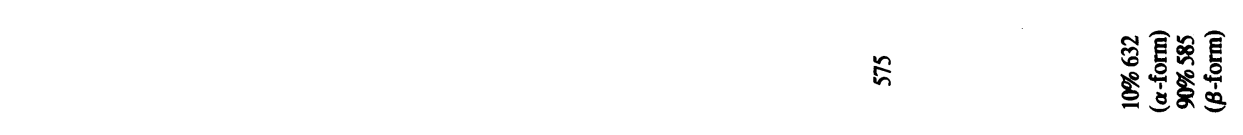
$\cong \quad=$
言
$\cong$
$\simeq \quad 0$
$\overline{\mathrm{z}}$

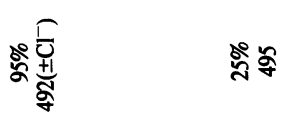

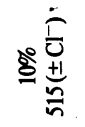

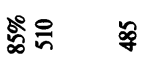

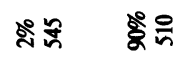

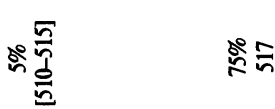

焉

sion

용 옹

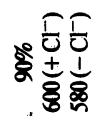

a $=$

$\simeq$

$\sim m$

廿

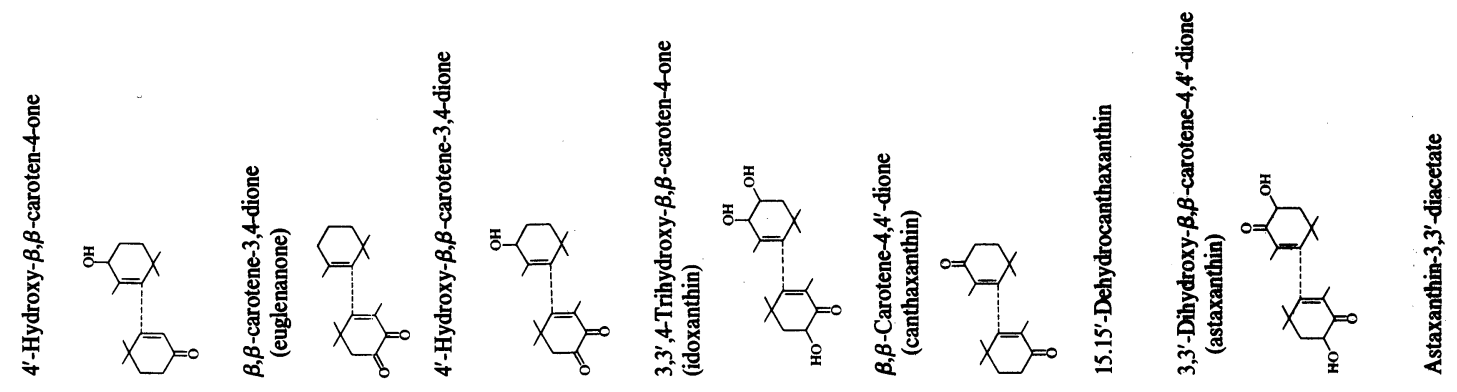




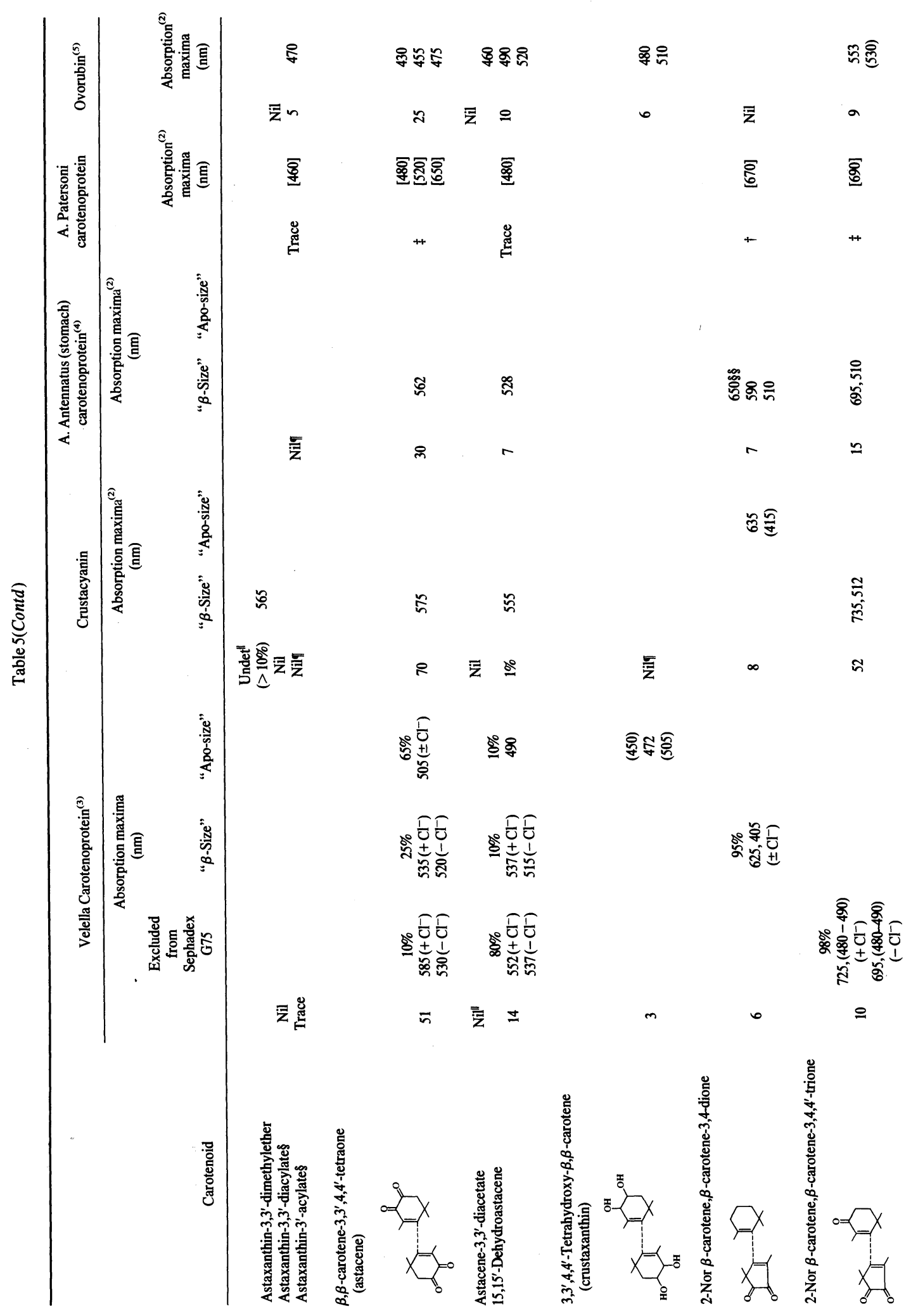




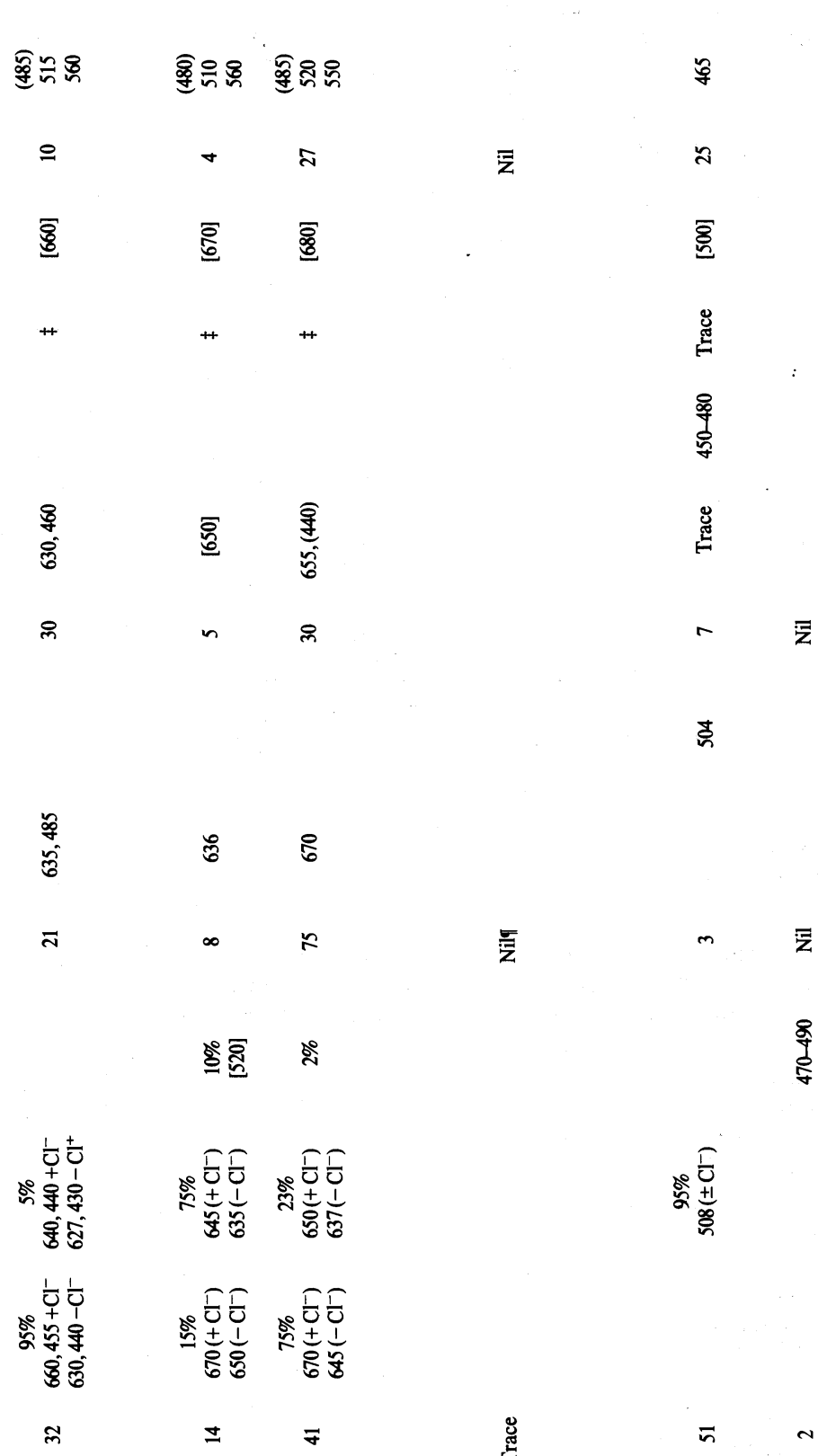

\begin{tabular}{|c|c|c|c|}
\hline$\varrho$ & $\nabla$ & $\tilde{A}$ & $\overline{\bar{z}}$ \\
\hline$\overline{8}$ & $\overline{8}$ & $\overline{\underline{g}}$ & \\
\hline + & + & + & \\
\hline
\end{tabular}

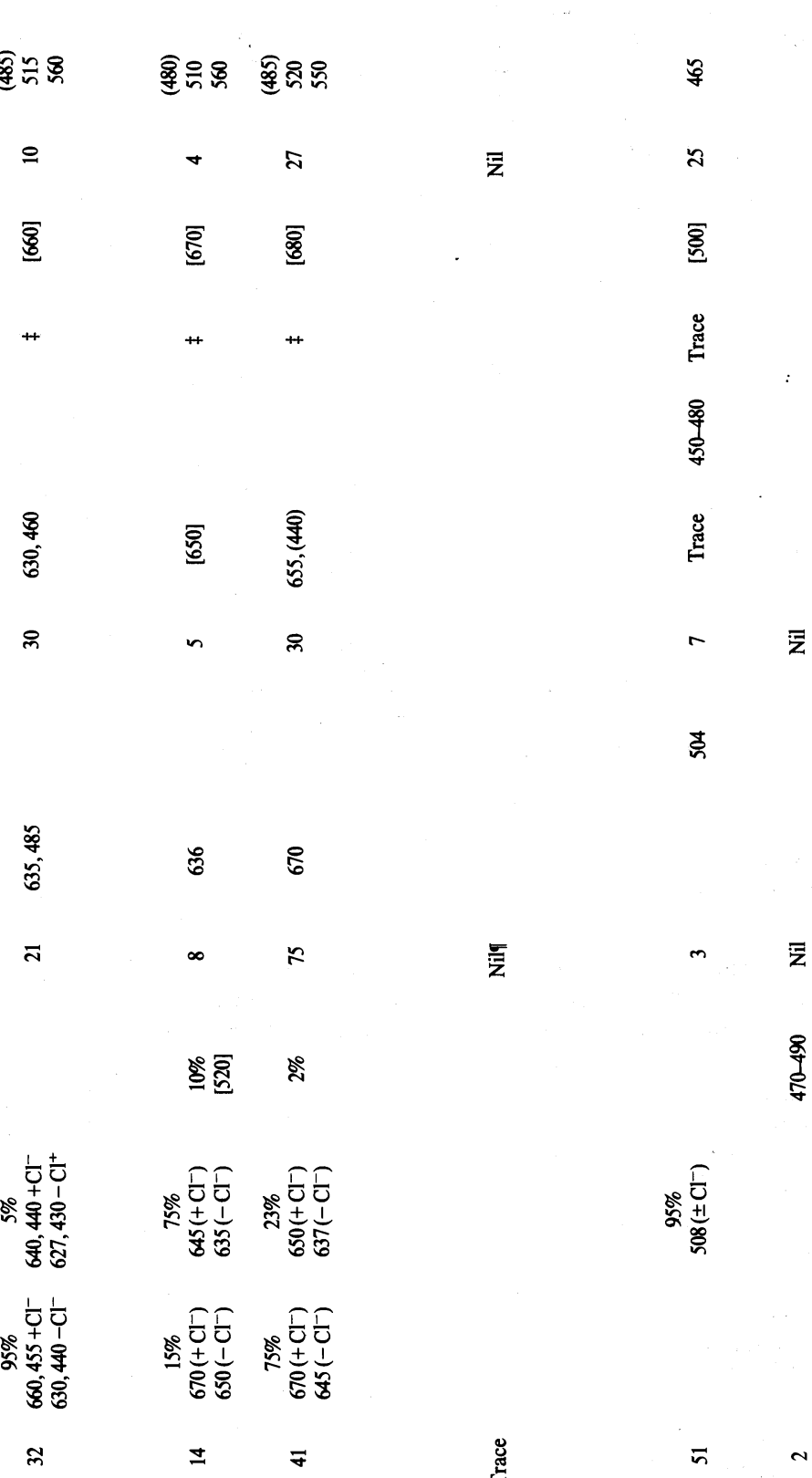

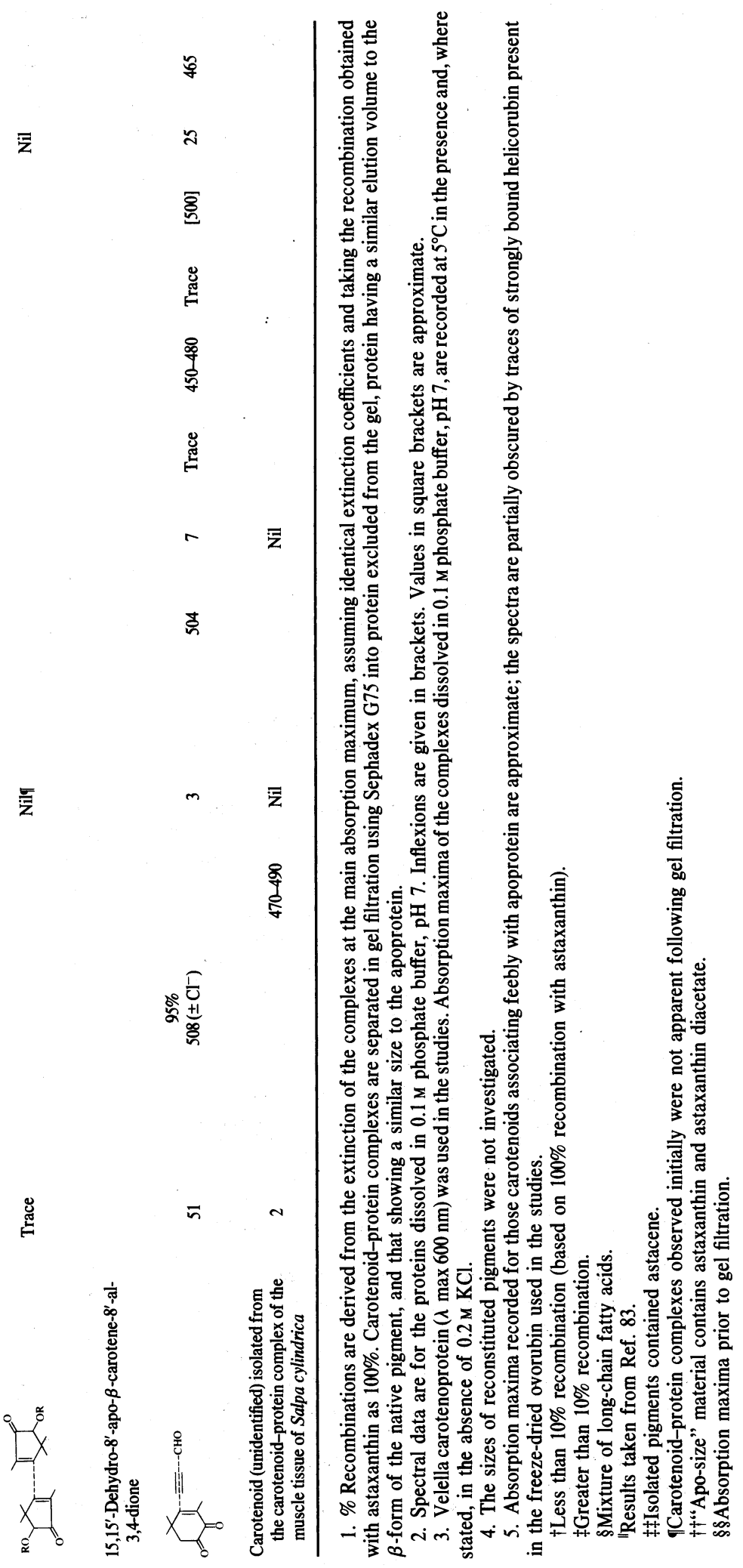

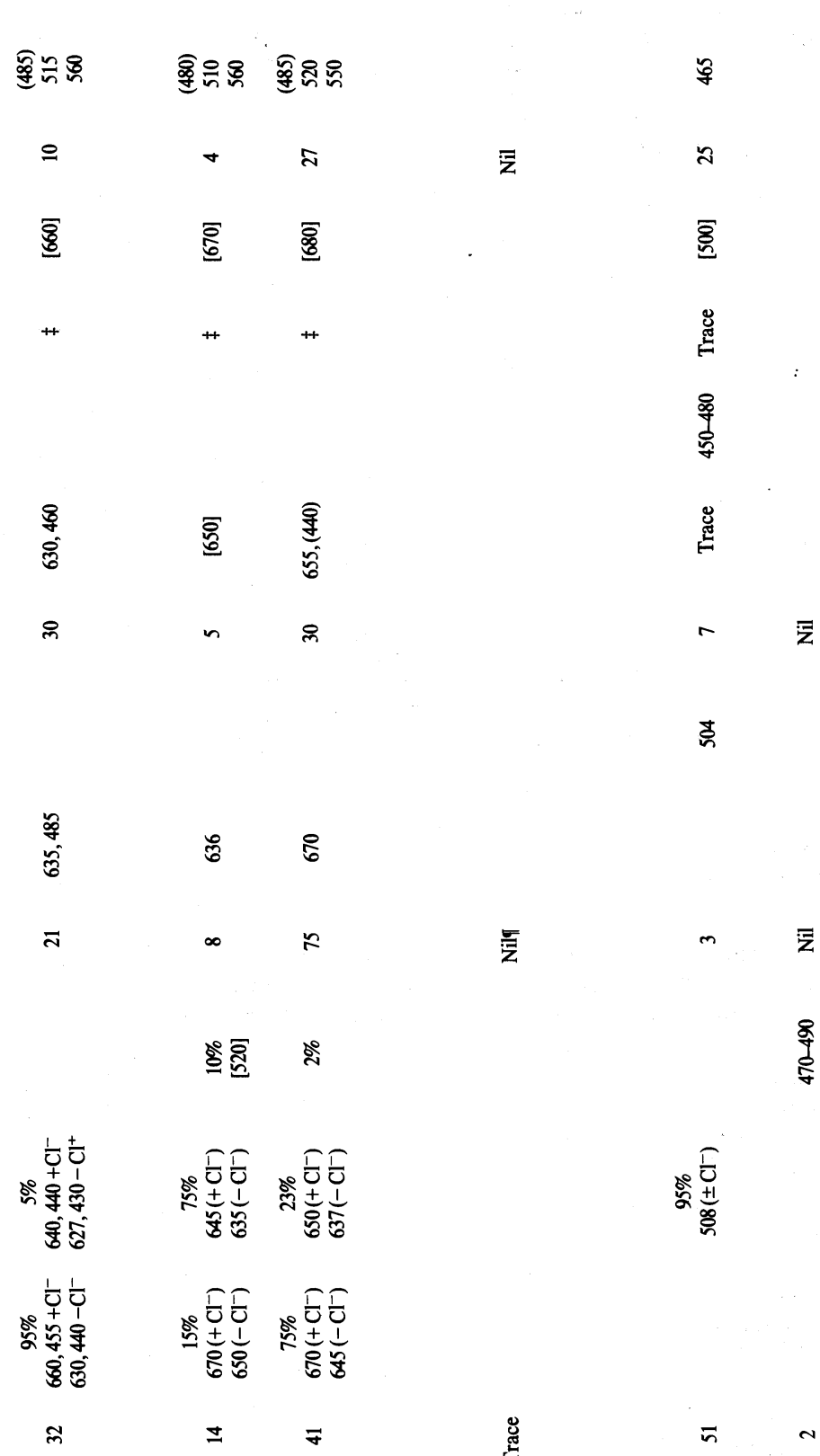

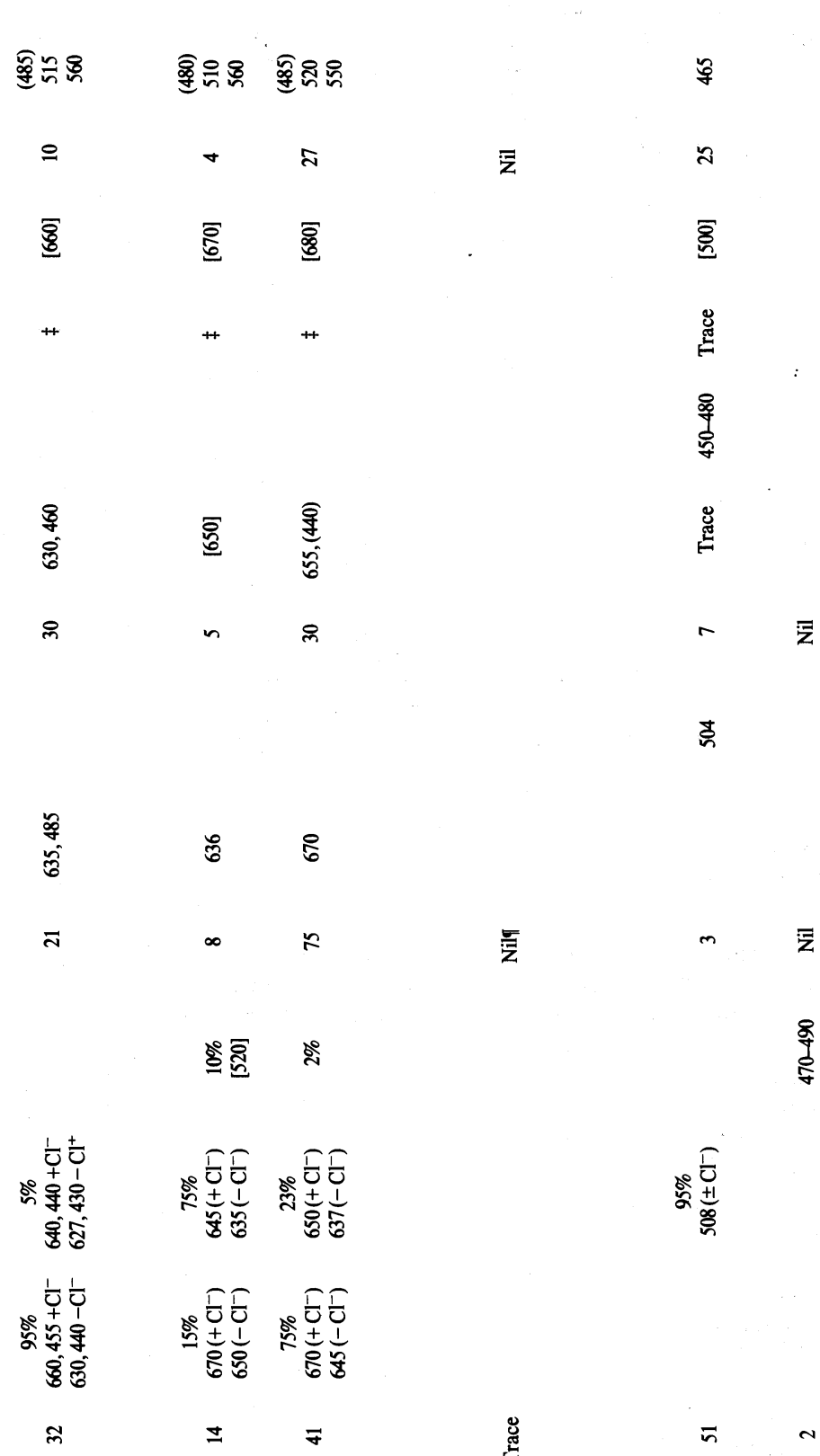

che
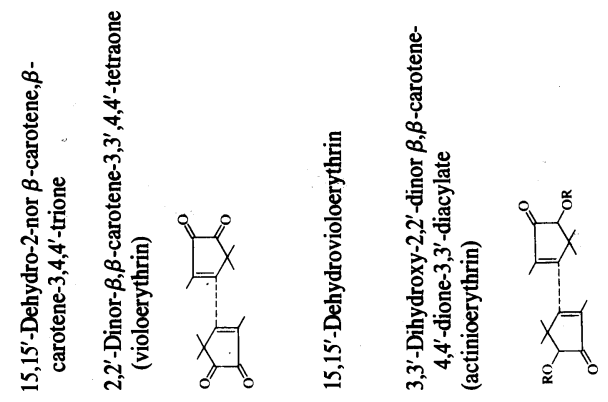

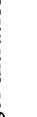


Table 6. Characteristics of the absorption spectra of carotenoproteins

\begin{tabular}{|c|c|c|c|c|c|}
\hline Species & Tissue & $\begin{array}{c}\lambda_{\max } \dagger \\
(\mathrm{nm})\end{array}$ & $\begin{array}{l}\mathrm{V} \frac{1}{2}\left(\mathrm{~cm}^{-1}\right) \ddagger \\
\times 10^{-2}\end{array}$ & $\begin{array}{c}\mathrm{E}_{\max }\left(\mathrm{cm}^{-1}\right) \S \\
\times 10^{-5}\end{array}$ & $\mathrm{f} \mathscr{1}$ \\
\hline \multirow[t]{3}{*}{ Aristeus antennatus $^{71}$} & Carapace & 593 & 43.0 & 1.23 & 2.46 \\
\hline & Mandibles & 595 & 44.0 & & $2.32^{\prime \prime}$ \\
\hline & Stomach & 588 & 43.0 & 1.24 & 2.56 \\
\hline Palinurus vulgaris $^{71}$ & Carapace & 560 & 45.0 & & $2.67^{\| \prime}$ \\
\hline Scyllarus arctus ${ }^{71}$ & Carapace & 616 & 46.0 & 1.20 & 2.70 \\
\hline \multicolumn{6}{|l|}{ Clibanarius } \\
\hline erythropus $^{71}$ & Exoskeleton & 620 & 41.0 & 1.26 & 2.34 \\
\hline Galathea strigosa $^{71}$ & Carapace & 589 & 46.0 & & $2.64^{\| \prime}$ \\
\hline Eriphia spinifrons $^{71}$ & Carapace & 536 & 42.0 & & $2.50^{4}$ \\
\hline Homarus gammarus $^{79}(\mathrm{~L})$. & Exoskeleton & 632 & 42.0 & 1.25 & 2.60 \\
\hline \multicolumn{6}{|c|}{ Labidocera } \\
\hline acutifrons ${ }^{72}$ & Hypodermis & 640 & 42.0 & 1.19 & 2.52 \\
\hline Labidocera sp. ${ }^{31}$ & Hypodermis & 630,660 & 43.0 & 1.26 & 2.54 \\
\hline \multicolumn{6}{|l|}{ Anomalocera } \\
\hline patersoni $^{31}$ & Hypodermis & 650 & 44.0 & 1.26 & 2.46 \\
\hline Velella sp. $\dagger^{\dagger}$ & Mantle & 620 & 40.0 & 1.28 & 2.63 \\
\hline \multirow{3}{*}{$\begin{array}{l}\text { Velella sp. } \\
\text { Porpita sp. }{ }^{31}+\dagger\end{array}$} & Mantle & 600 & 39.0 & 1.27 & 2.38 \\
\hline & Mantle \& & & & & \\
\hline & tentacles & 650 & 43.4 & 1.28 & 2.60 \\
\hline \multicolumn{6}{|l|}{ Astaxanthin } \\
\hline In pyridine $^{79}$ & & 492 & 42.0 & 1.12 & 2.35 \\
\hline In hexane $e^{79}$ & & 472 & 42.0 & 1.24 & 2.60 \\
\hline
\end{tabular}

$\nmid$ Position of main absorption maximum at room temperature for the pigment dissolved in $0.2 \mathrm{M}$ phosphate buffer $\left(\mathrm{KH}_{2} \mathrm{PO}_{4}-\mathrm{Na}_{2} \mathrm{HPO}_{4}\right)$, $\mathrm{pH} 7$.

$\ddagger$ Half-band width.

\$Molar extinction coefficient, based on astaxanthin content.

IOscillator strength.

"Assuming a value of $1.23 \times 10^{5}$ for $\mathrm{E}_{\max }$.

$\dagger+$ Carotenoprotein dissolved in $1 \mathrm{M} \mathrm{KCl-0.05} \mathrm{M}$ phosphate buffer, $\mathrm{pH} 7$.

derivatives of retinenal to produce visual pigments in which the absorption maxima of the polyenes are still strongly displaced to longer wavelength, ${ }^{98,100}$ is difficult to reconcile with the twisting mechanism.

The strong optical activity of the bound astaxanthin in $\alpha$ - and $\beta$-crustacyanin, ${ }^{79}$ and of retinal in rhodopsin ${ }^{79,110,111}$ and retinochrome, ${ }^{112}$ has similarly been attributed to extrinsic stereospecific twisting of the polyenes which introduces asymmetry into the chromophores. The magnitude of the induced optical activity of retinal in rhodopsin can equally well be explained by a Kirkwoodtype coupled oscillator mechanism, involving the interaction of the polyene transition with the transition of a neighbouring $(<15 \AA)$ aromatic side chain. ${ }^{98,110,113}$ The $\mathrm{ORD}$ and circular dichroism (CD) spectra of the crustacyanins in the visible region exhibit evidence of degenerate exciton interaction. The $C D$ spectrum of $\beta$-crustacyanin has negative and positive Cotton effects above and below the position of the absorption maximum, respectively. ${ }^{79}$ The splitting of the excitation may be the result of intermolecular interaction of the transition dipoles of carotenoids at an angle to one another and attached to closely situated apoprotein units. ${ }^{79,82}$ An alternative explanation, previously suggested for the exciton splitting of the $C D$ spectrum of $N$-all-transretinylidene-poly-L-lysine, ${ }^{114}$ could be mutual induction of optical activity in the chromophores due to an asymmetrical arrangement of the (adjacent) binding sites. The Velella pigment, the only other carotenoprotein of which the optical activity has been investigated, resembles crustacyanin in showing a large maximal molar ellipticity value for the bound carotenoid. Splitting of the excitation, inverted in shape compared with that in crystacyanin, is seen only with the form of the protein with absorption maximum at $620 \mathrm{~nm}$ and only in the presence of chloride ions (Fig. 3); ${ }^{31}$ there appears to be no major change in the protein conformation in this process, as revealed in the u.v. CD spectra.

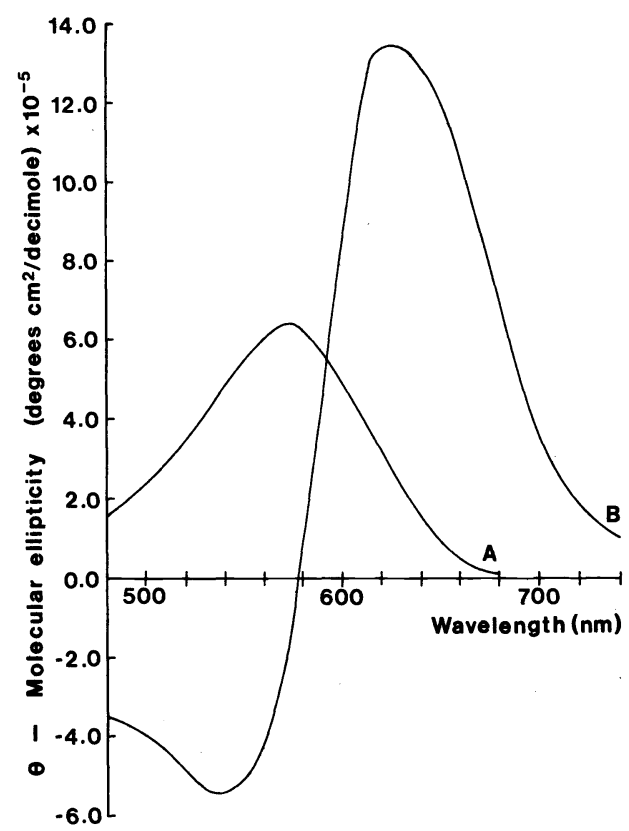

Fig. 3. Circular dichroism spectrum of Velella carotenoprotein $(\lambda$ max $620 \mathrm{~nm})$ dissolved in $0.2 \mathrm{M}$ phosphate $\left(\mathrm{KH}_{2} \mathrm{PO}_{4}-\mathrm{Na}_{2} \mathrm{HPO}_{4}\right)$ buffer, $\mathrm{pH} 7$, in the absence $(\mathrm{A})$ and presence of $(\mathrm{B})$ of $0.5 \mathrm{M} \mathrm{KCl}$. 
The absorption spectra of $\alpha$ - and $\beta$-crustacyanin, broad and featureless at room temperature, sharpen somewhat at $77^{\circ} \mathrm{K}$ to reveal incipient vibrational structure. The spectrum of astaxanthin, the chromophore, sharpens markedly at $77^{\circ} \mathrm{K}$ to reveal a typical vibrational progression of $1270 \pm 60 \mathrm{~cm}^{-1} \cdot{ }^{115}$ Although the circular dichroism spectra of $\alpha$ - and $\beta$-crustacyanin show double-peaked degenerate exciton interaction under the long-wavelength long-axis polarised band, no splitting is visible under the short-axis polarised cis peak at $c a .2700 \mathrm{~cm}^{-1}$. ${ }^{115}$ In principle geometrical information about the relative disposition of a pair of carotenoids can be extracted from the spectrum of $\beta$-crustacyanin. In practice this is difficult to achieve unambiguously. However, the lack of degenerate exciton splitting under the cis peaks is evidence that the directions of these two short axis transition dipole moments on interacting carotenoids must be parallel. Thus the planes containing the long axis of each carotenoid must also be parallel. Further analysis of the degenerate exciton interaction under the long wavelength band gave an angle of $\mathrm{ca} .77^{\circ}$ between the two long axes of the carotenoids. The distance between their centres was not obtained with certainty but must lie in the range 4-10 $\mathrm{A}$ in order to give effects of the magnitude observed. In the aggregated $\alpha$-derivative a bond angle of $72^{\circ}$ between the long axes was deduced. ${ }^{115}$ At these distances the London dispersion-Van der Waals forces between two oriented carotenoids ${ }^{116}$ may be of sufficient magnitude to make an appreciable contribution to the dimerisation of the apoprotein units.

\section{Nature of the carotenoid-binding sites}

One can only speculate on the nature of the carotenoidbinding sites in carotenoproteins. The carotenoid is believe to be buried in the association, removed from water, ${ }^{78}$ but with the 4 - and $4^{\prime}$-keto groups near the protein surface. ${ }^{79}$ The proposed strain mechanism for the binding requires close fit between the polypeptide and methyl groups of the polyene chain and firm anchoring of the $\beta$-ionone rings. ${ }^{79}$ The high content of small amino acids, particularly in proteins of low minimum molecular weight (based on astaxanthin contents), may facilitate an intimate fit between polyene and polypeptide backbone. It is probable that the structures of carotenoproteins are composed mainly of random coil and $\beta$-conformations. The low content of leucine, the main stabilising influence in the inner sections of $\alpha$-helices, ${ }^{117}$ and the high content of helix-breaking ${ }^{118,9}$ amino acids (proline, serine, glycine and asparagine) indicate that the proteins must have low helical contents. Confirmation of this, for crustacyanin and Velella carotenoprotein, has come from u.v. CD measurements. The helical content of crustacyanin has been estimated to be $6 \% .^{79}$ The Velella carotenoprotein may have a configuration composed almost entirely of $\beta$-structure. ${ }^{31}$ Amino acids which occur in high frequency in $\beta$-structures (isoleucine, valine, threonine and glutamine $)^{117,121}$ are not infrequent in carotenoproteins. A large number of $\beta$-bends ${ }^{120}$ in the structures, assisting the formation of anti-parallel $\beta$-pleated sheets may result from the high contents of aspartic acid, serine, threonine and proline. The repeat distance between similarly oriented groups $(6.68 \AA)^{122}$ in $\beta$-pleated sheet structures is of similar magnitude to the distance between methyl groups in the polyene chain. ${ }^{123}$ It is suggested that immobilisation of these methyl groups occurs through binding to lengths of $\beta$-pleated sheet in which small substituents (e.g. alanine) favour strong hydrophobic interaction, as exists between polyene chains in canthaxanthin crystals. ${ }^{123}$ The $\beta$-ionone ring, twisted out of the plane of the polyene chain about the 6-7 single bond, may interact hydrophobically through a methyl group in the 1-position with a flexible residue (e.g. isoleucine) of the $\beta$-pleated sheet. It is also proposed, in view of the importance of 4-keto groups for combination with apoprotein, that the $\beta$-ionone rings are bound through these groups by hydrogen-bonding to imide groups of peptide bonds on peripheral chains of $\beta$-pleated sheet structures (Fig. 4). The hydrogen bonding between peripheral and adjacent chains of the $\beta$-structure would ensure, through electron withdrawal, a stronger hydrogenbonding of the carotenoid than would be obtained with the single chain. The 5- and 5'-methyl groups of the prosthetic group may be made secure by bonding to an adjacent hydrophobic residue (e.g. isoleucine). The binding can be additionally stabilised, as molecular models show (preferred hydrogen-bond angles and distances ${ }^{124}$ being maintained) by hydrogen-bonding of the 3S- and 3'S-hydroxy groups of the carotenoid to the neighbouring peptide bond carbonyl groups. The relative orientation of the pieces of $\beta$-structure binding the carotenoid would then control the twisting of the polyene and consequently the absorption maximum of the pigment.

\section{BACTERIAL AND PLANT CAROTENOID-PROTEIN COMPLEXES AND VITAMIN A-PROTEINS}

A number of lipoprotein particles or complexes containing chlorophyll and/or cytochromes and noncovalently bound carotenoids, in which there is some selectivity in the nature of the associated carotenoids, have been isolated from membranes of plant chloroplasts. ${ }^{125-9}$ The complexity of the particles precludes any meaningful discussion as to the mode of binding of the carotenoid component, which may involve protein, lipid and chlorophyll. ${ }^{133}$ The preparation and properties of conjugates of $\beta$-carotene with insoluble ${ }^{131}$ and soluble $e^{134}$ chloroplast lamellar(lipo)protein, free from other components, have recently been reviewed. It is still controversial whether these are natural complexes, or artifacts. These and other plant "carotenoproteins"132,135 may be various types of carotenoid aggregates in stabilised suspension, ${ }^{82,134,136,137}$ or may be formed by unspecific association of carotenoid with hydrophobic protein during isolation (cf. 107, 144).

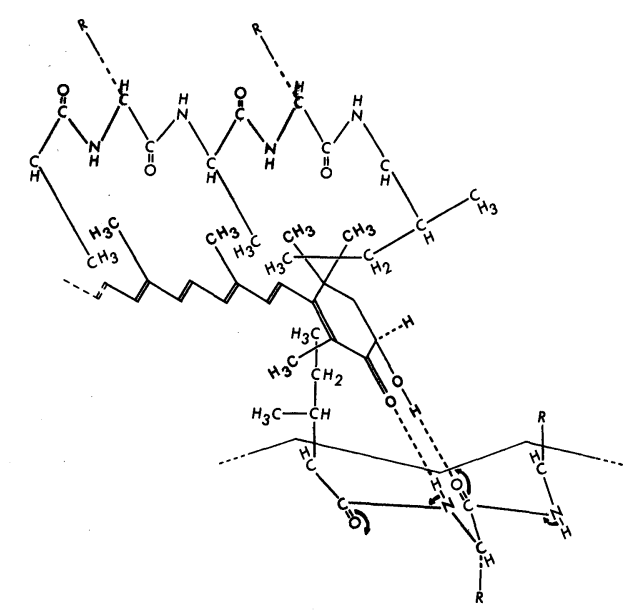

Fig. 4. Proposed mode of binding of astaxanthin in carotenoproteins. 
Table 7. Comparison of compositions (mol\%) of bacterial and plant carotenoid-protein complexes and vitamin A-proteins, in terms of amino acid sets, with those of membrane lipoproteins and different groups of soluble proteins

\begin{tabular}{|c|c|c|c|c|c|}
\hline Protein & $\begin{array}{l}\text { Apolar residues }(\mathrm{A}) \dagger \\
\quad(\mathrm{mol} \%)\end{array}$ & $\begin{array}{l}\text { Polarity index }(\mathrm{P}) \ddagger \\
\quad(\mathrm{mol} \%)\end{array}$ & $\begin{array}{l}\mathrm{P} / \mathrm{A} \\
\text { ratio }\end{array}$ & $\begin{array}{l}\text { Small§ } \\
(\mathrm{mol} \mathrm{\% )}\end{array}$ & $\begin{array}{l}\text { Charged } q \\
(\mathrm{~mol} \%)\end{array}$ \\
\hline Rhodopsin (bovine) ${ }^{151}$ & 29.3 & 39.9 & 1.4 & 18.0 & 22.7 \\
\hline \multicolumn{6}{|l|}{ Rhodopsin (treated with ${ }^{147}$} \\
\hline chymotrypsin) & 36.2 & 37.7 & 1.0 & 16.6 & 23.9 \\
\hline $\mathrm{N}$-retinylidene peptide ${ }^{148}$ & 40.0 & 20.0 & 0.5 & 30.0 & - \\
\hline Bacteriorhodopsin $^{152}$ & 34.8 & 35.5 & 1.0 & 21.4 & 23.1 \\
\hline \multicolumn{6}{|l|}{ Spirilloxanthin-glycolipoprotein ${ }^{139}$} \\
\hline complex (Rhodospirillum rubrum) & 29.4 & 41.1 & 1.4 & 22.3 & 28.7 \\
\hline \multicolumn{6}{|l|}{ Detergent-soluble carotenoid- } \\
\hline flava) & 38.2 & 38.4 & 1.0 & 19.4 & 16.7 \\
\hline \multicolumn{6}{|l|}{$\begin{array}{l}\text { Carotenoidglycoside-peptide } \\
\text { (S. flava, fraction } 4 \text { (iii)), ether- }\end{array}$} \\
\hline $\begin{array}{l}\text { Bacterioruberinglycoside-peptide } \\
\text { (Sarcina morrhuae), water-soluble } \\
\text { following saponifaction step }{ }^{143}\end{array}$ & \multicolumn{2}{|c|}{ Bacterioruberinglycoside-peptide } & 1.6 & 24.1 & 35.3 \\
\hline \multicolumn{6}{|l|}{$\beta$-carotene-binding lamellar protein } \\
\hline (spinach chloroplast), water-soluble ${ }^{134}$ & 31.0 & 39.7 & 1.3 & 20.1 & 27.7 \\
\hline $\begin{array}{l}\beta \text {-carotene-binding lamellar protein } \\
\quad \text { (spinach chloroplast), water-insoluble }{ }^{133}\end{array}$ & 31.0 & 39.5 & 1.3 & 20.1 & 27.7 \\
\hline $\begin{array}{l}\beta \text {-carotene-containing cytochrome } b^{559} \\
\text { (spinach chloroplast) }^{129}\end{array}$ & 33.0 & 39.5 & 1.2 & 17.6 & 18.5 \\
\hline $\begin{array}{l}\text { Retinol-binding protein (serum) } \\
\text { (average composition: rat, porcine, } \\
\text { monkey, human) }\end{array}$ & 25.5 & 51.1 & 2.0 & 13.0 & 37.6 \\
\hline Soluble lipoproteins ${ }^{95}$ & $27.3 \pm 2.5$ & $50.0 \pm 2.4$ & $1.8 \pm 0.2$ & $12.8 \pm 1.4$ & $33.8 \pm 4.0$ \\
\hline Soluble proteins $\mathrm{s}^{95}$ & $23.9 \pm 3.6$ & $49.1 \pm 3.1$ & $2.1 \pm 0.5$ & $14.3 \pm 4.2$ & $33.1 \pm 3.1$ \\
\hline Soluble oligomeric proteins ${ }^{95}$ & $27.5 \pm 2.8$ & $45.1 \pm 3.3$ & $1.7 \pm 0.6$ & $16.6 \pm 3.9$ & $31.0 \pm 3.3$ \\
\hline Membranous lipoproteins ${ }^{95}$ & $29.9 \pm 2.8$ & $42.7 \pm 5.7$ & $1.4 \pm 0.3$ & $16.9 \pm 3.0$ & $28.8 \pm 5.8$ \\
\hline
\end{tabular}

$\dagger$ Apolar residues: $: 55$ Val, Ileu, Leu, Phe, Met.

$\ddagger$ Polarity index: ${ }^{94}$ sum of mol \% values of Asp, Thr, Ser, Glu, Lys, His, Arg.

§Small amino acids: ${ }^{95}$ Ala, Gly.

TCharged amino acids: ${ }^{95}$ Asp, Glu, Arg, Lys.

Functional particles containing bacteriochlorophyll and non-covalently bound carotenoids have, likewise, been isolated from the chromatophores of photosynthetic bacteria. ${ }^{138}$ The spectra of carotenoid-protein complexes, freed from bacteriochlorophyll derived from Rhodospirillum rubrum particles, are hypsochromically shifted from that of the carotenoid in the native or free state $^{131,13840}$ (cf. the spectra of some plant ${ }^{135}$ and invertebrate ${ }^{33-6,82}$ carotenoid-protein complexes). The low molecular weight and the low carotenoid content of the purified $R$. rubrum spirilloxanthin-glycolipoprotein, ${ }^{140}$ make it unlikely that this complex is a carotenoid aggregate ${ }^{131}$ The relationship between the state of the carotenoid in the complex and that in vivo, however, is yet to be established. An unspecific combination is not excluded.

Detergent-soluble complexes, in which a carotenoid glucoside is covalently bound to lipoprotein, and ethersoluble and water-soluble carotenoidglycoside-peptides have been isolated from the membranes of nonphotosynthetic bacteria and partially characterised. ${ }^{141-3}$

Recent reviews and articles on the retinol-binding protein of serum, ${ }^{101,145,153}$ retinochrome, ${ }^{12,146}$ bacteriorhodopsin ${ }^{147}$ and the spectra of visual pigments ${ }^{110}$ are relevant to the present review insofar as they throw light on polyene-protein interactions.

Most of the proteins considered in this section are part of membrane structures and have amino acid composi- tions characteristic of membrane proteins, often with high contents of small amino acids. The retinol-binding protein has an overall composition similar to those of typical soluble lipoproteins, while the carotenoidglycosidepeptides of Sarcina flava and Sarcina morrhuae bear some resemblance in the different groups of amino acids to the invertebrate carotenoproteins (Table 7).

Acknowledgements - I am deeply indebted to Professor D. F. Cheesman (Bedford College) for invaluable advice and assistance during the preparation of the review and to Dr. B. M. Gilchrist (Bedford College) for kindly criticising the manuscript. I would like to thank Dr. B. M. Gilchrist, P. J. Herring (National Institute of Oceanography, Surrey) and A. J. Thomson (University of East Anglia) for allowing me to mention their unpublished observations. I am grateful to Professor B. C. L. Weedon (Queen Mary College, London) for kindly supplying synthetic carotenoids and to Dr. P. M. Scopes (Westfield College, London) for measuring the $\mathrm{CD}$ spectra of the Velella pigments.

Addendum -In a recent paper (J. Exp. Zool. 188, 289-296 (1974)) C. W. Lui, B. A. Sage and J. D. O'Connor have demonstrated that ovaries of Procambarus sp. are capable, in vitro, of forming at least part of the lipovitellin molecule.

\section{REFERENCES}

${ }^{1}$ D. F. Cheesman, W. L. Lee and P. F. Zagalsky, Biol. Rev. 42, 132 (1967).

${ }^{2} \mathrm{H}$. Thommen, Carotenoids (editor 0. Isler) Chap. 8. Birkhäuser, Basel (1971). 
${ }^{3}$ D. Bellamy, Comp. Biochem. Physiol. 17, 1137 (1965).

${ }^{4}$ D. G. Cornwell, F. A. Kruger and H. B. Robinson, J. Lipid Res. 3, 65 (1962).

${ }^{5}$ M. Fingerman, Physiol. Rev. 45, 296 (1965).

${ }^{6} \mathrm{~T}$. W. Goodwin, The Physiology of Crustacea (editor T. H. Waterman), Vol. 1, Chap. 3, Academic Press, New York (1960).

${ }^{7}$ R. Elofsson and E. Hallberg, J. Ultrastruct. Res. 44, 421 (1973).

${ }^{8}$ D. L. Fox, Comp. Biochem. Physiol. 44B, 953 (1973).

${ }^{9} \mathrm{P}$. J. Herring, J. Marine Biol. Assoc. UK 53, 539 (1973).

${ }^{10}$ D. L. Fox and T. S. Hopkins, Comp. Biochem. Physiol. 17, 841 (1966).

${ }^{11}$ D. L. Fox and T. S. Hopkins, Comp. Biochem. Physiol. 19, 267 (1966).

${ }^{12}$ D. L. Fox and D. W. Wilkie, Comp. Biochem. Physiol. 36, 49 (1970).

${ }^{13}$ D. L. Fox, Comp. Biochem. Physiol. 43B, 919 (1972).

${ }^{14}$ P. J. Herring, Symp. zool. Soc. Lond. 19, 215 (1967)

${ }^{15}$ P. J. Herring, J. Marine Biol. Assoc. UK 52, 179 (1972).

${ }^{16}$ P. F. Zagalsky, D. F. Cheesman and H. J. Ceccaldi, Comp. Biochem. Physiol. 22, 851 (1967).

${ }^{17}$ B. M. Gilchrist and W. L. Lee, Comp. Biochem. Physiol. 42B, 263 (1972).

${ }^{18}$ D. L. Fox, T. S. Hopkins and D. B. Zilversmit, Comp. Biochem. Physiol. 14, 641 (1965).

${ }^{19} \mathrm{G}$. C. Chen and J. P. Kane, Biochemistry 13, 3330 (1974).

${ }^{20}$ P. J. Herring, Proc. 9 th Europ. Marine Biol. Symp. 299 (1975).

${ }^{21} P$. J. Herring, unpublished observations.

${ }^{22}$ D. L. Fox, V. E. Smith and A. A. Wolfson, Experientia 23, 12 (1967).

${ }^{23}$ A. R. Holter, Comp. Biochem. Physiol. 28, 675 (1968).

${ }^{24}$ A. H. Warner, J. G. Puodziukas and F. J. Finamore, Exp. Cell Res. 70, 365 (1972).

${ }^{25}$ P. F. Zagalsky and B. M. Gilchrist, Comp. Biochem. Physiol., In press.

${ }^{26}$ D. F. Cheesman and J. P. Prebble, Comp. Biochem. Physiol. 17, 929 (1966).

${ }^{27}$ W. Fyffe and J. D. O'Connor, Comp. Biochem. Physiol. 47B, 851 (1974).

${ }^{28}$ H. J. Ceccaldi, D. F. Cheesman and P. F. Zagalsky, Compt. Rend. Soc. Biol. 160, 587 (1966).

${ }^{29}$ D. L. Fox, V. Elliott Smith and A. A. Wolfson, Experientia 23, 965 (1967).

${ }^{30}$ D. A. Norden, Comp. Biochem. Physiol. 42B, 569 (1972).

${ }^{31} \mathrm{P}$. F. Zagalsky and P. J. Herring. Papers in preparation.

${ }^{32}$ B. M. Gilchrist, Unpublished observations.

${ }^{33}$ B. M. Gilchrist, Comp. Biochem. Physiol. 24, 123 (1968).

${ }^{34}$ W. L. Lee, Comp. Biochem. Physiol. 18, 17 (1966).

${ }^{35}$ W. L. Lee and B. M. Gilchrist, J. exp. Marine Biol. Ecol. 10, 1, (1972).

${ }^{36}$ W. L. Lee, Comp. Biochem. Physiol. 19, 13 (1966).

${ }^{37}$ J. Green, Biol. Rev. 40, 580 (1965).

${ }^{38}$ J. Green, J. Zool. Lond. 147, 174 (1966).

${ }^{39}$ P. J. Herring, Comp. Biochem. Physiol. 24, 205 (1968).

${ }^{40}$ P. J. Herring, Comp. Biochem. Physiol. 24, 187 (1968).

${ }^{41}$ R. A. Wallace, S. L. Walker and P. V. Hauschka, Biochemistry 6, 1582 (1967).

${ }^{42} \mathrm{~F}$. Leuenberger and H. Thommen, J. Insect Physiol. 16, 1855 (1970).

${ }^{43}$ R. A. Wallace, Biochim. Biophys. Acta 74, 505 (1963).

${ }^{44}$ J. L. Oncley, F. R. W. Gurd and M. Melin, J. Am. chem. Soc. 72, 458 (1950).

${ }^{45}$ R. A. Wallace, Analyt. Biochem. 11, 297 (1965).

${ }^{46} \mathrm{H}$. J. Ceccaldi. Thèse de doctorat ès-sciences naturelles, Université d'Aix-Marseille (1968).

${ }^{47}$ C. Jacobs and W. P. Jencks, Biol. Bull. 129, 410 (1965).

${ }^{48}$ E. W. Bergink and R. A. Wallace, J. Biol. Chem. 249, 2897 (1974).

${ }^{49}$ E. W. Bergink, R. A. Wallace, J. A. Van de Berg, E. S. Bos, M. Gruber and A. B. Geert, Amer. Zool. 14, 1177 (1974).

${ }^{50}$ R. K. Dejmal and V. J. Brookes, J. Biol. Chem. 247, 869 (1972).

${ }^{51}$ P. F. Zagalsky, unpublished observations.

${ }^{52}$ R. Smith, J. R. Dawson and C. Tanford, J. Biol. Chem. 247, 3376 (1972).

${ }^{53}$ W. H. Cook and W. G. Martin, Structural and Functional Aspects of Lipoproteins in Living Systems (editors E. Tria and A.
M. Scanu), Chap. C8. Academic Press, New York (1969).

${ }^{54} \mathrm{~A}$. Scanu, Structural and Functional Aspects of Lipoproteins in Living Systems (editors E. Tria and A. M. Scanu), Chap. C3. Academic Press, New York (1969).

${ }^{55}$ S. Margolis, Structural and Functional Aspects of Lipoproteins in Living Systems (editors E. Tria and A. M. Scanu), Chap. C2. Academic Press, New York (1969).

${ }^{56}$ P. F. Zagalsky, Comp. Biochem. Physiol. 41B, 385 (1972).

${ }^{57}$ J. J. Marchalonis and J. K. Weltman, Comp. Biochem. Physiol. 38B, 609 (1971).

${ }^{58}$ J. K. Weltman and R. M. Dowben, Proc. Natn. Acad. Sci., U.S.A. 70, 3230 (1973).

${ }^{59}$ R. G. Adijodi, Indian J. Exp. Biol. 6, 144 (1968).

${ }^{60}$ M. S. Kerr, Develop. Biol. 20, 1 (1969).

${ }^{61}$ Y. Croisille, Amer. Zool. 14, 1219 (1974).

${ }^{62}$ H. J. Ceccaldi, Rec. Trav. Stat. mar. Endoume, 44,60, 403 (1968).

${ }^{63}$ H. W. Beams and R. G. Kessel, J. Cell Biol. 18, 621 (1963).

${ }^{64} \mathrm{~F}$. J. Finamore and J. S. Clegg, The Cell Cycle (editors G. L. Padilla, G. L. Whitson and I. Cameron), Chap. 12. Academic Press, New York (1969).

${ }^{65}$ A. H. Warner and D. K. McClean, Develop. Biol. 18, 279 (1968).

${ }^{66} \mathrm{~W}$. Wieser, J. Marine Biol. Assoc. UK 45, 507 (1965).

${ }^{67}$ W. L. Lee, Ecology 47, 930 (1966).

${ }^{68}$ G. C. Genofre, Compt. Rend Acad. Sci., Ser. D, 276, 2269 (1973).

${ }^{69}$ B. H. Davies, W-J. Hsu and C. O. Chichester, Comp. Biochem. Physiol. 33, 601 (1970).

${ }^{70}$ D. Arens, W. Seilmeier, F. Weber, G. Kloos and W. Grosch, Biochim. Biophys. Acta 327, 295 (1973).

${ }^{71}$ P. F. Zagalsky, H. J. Ceccaldi and R. Daumas, Comp. Biochem. Physiol. 34, 579 (1970).

${ }^{72}$ P. F. Zagalsky and P. J. Herring, Comp. Biochem. Physiol. 41B, 397 (1972).

${ }^{73}$ H. Nakagawa, M. Kayama and S. Askawa, J. Fac. Fisheries Animal Husbandry, Hiroshima Univ. 12, 21 (1973).

${ }^{74}$ H. Nakagawa, M. Kayama and S. Asakawa, J. Fac. Fisheries Animal Husbandry, Hiroshima Univ. 13, 1 (1973).

${ }^{75}$ H. Nakagowa, M. Kayama and S. Asakawa, J. Fac. Fisheries Animal Husbandry, Hiroshima Univ. 10, 61 (1971).

${ }^{76}$ H. J. Ceccaldi and P. F. Zagalsky, Comp. Biochem. Physiol. 21, 435 (1967).

${ }^{77}$ R. Kuhn and H. Kühn, Angew. Chem. 78, 979 (1966).

${ }^{78}$ R. Kuhn and H. Kühn, Europ. J. Biochem. 2, 349 (1967).

${ }^{79} \mathrm{M}$. Buchwald and W. P. Jencks, Biochemistry 7, 844 (1968).

${ }^{80}$ D. F. Cheesman, P. F. Zagalsky and H. J. Ceccaldi, Proc. Roy. Soc. B, 164, 130 (1966).

${ }^{81}$ W. P. Jencks and B. Buten, Arch. Biochem. Biophys. 107, 511 (1964).

${ }^{82} \mathrm{M}$. Buchwald and W. P. Jencks, Biochemistry 7, 834 (1968).

${ }^{83}$ R. M. Quarmby, Ph.D. Thesis, London University (1971).

${ }^{84}$ R. M. Quarmby, D. Nordan, P. F. Zagalsky, H. J. Ceccaldi and R. Daumas, Paper in preparation.

${ }^{85}$ T. Yoshimura and T. Isemura, J. Biochem. 69, 969 (1971).

${ }^{86}$ G. D. Sabato and N. O. Kaplan, J. Biol. Chem. 239, 438(1964)

${ }^{87}$ J. Heller and J. Horwitz, J. Biol. Chem. 248, 6308 (1973).

${ }^{88}$ E. W. Abrahamson and S. E. Ostroy, Prog. Biophys. Mol. Biol. 17, 181 (1967).

${ }^{89}$ D. B. Gammack, J. H. Raper, P. F. Zagalsky and R. Quarmby, Comp. Biochem. Physiol. 40B, 295 (1971).

${ }^{90} \mathrm{~A}$. Kropf, Vision Res. 7, 811 (1967).

${ }^{91}$ W. L. Lee and P. F. Zagalsky, Biochem. J. 101, 9c (1966).

${ }^{92}$ B. C. L. Weedon, Carotenoids (editor O. Isler), Chap. 5, Birkhäuser, Basel (1971).

${ }^{93}$ M. H. Smith, J. Theoret. Biol. 13, 261 (1966).

${ }^{94}$ R. A. Capaldi and G. Vanderkooi, Proc. Natn. Acad. Sci. U.S.A. 69, 930 (1972).

${ }^{95}$ F. T. Hatch and A. L. Bruce, Nature, Lond. 218, 1166 (1968).

${ }^{96}$ C. G. Bigelow, J. Theoret. Biol. 16, 187 (1967).

${ }^{97}$ Y. Nozaki and C. Tanford, J. Biol. Chem. 246, 2211 (1971).

${ }^{98}$ A. Kropf, B. P. Whittenberger, S. P. Goff and A. S. Waggoner, Exp. Eye Res. 17, 591 (1973).

${ }^{99}$ C. Enzell and G. Francis, Acta Chem. Scand. 22, 344 (1968).

${ }^{100}$ P. Blatz, M. Lin, P. Balasubramaniyan, V. Balasubramaniyan and P. B. Dewhurst, J. Am. chem. Soc. 91, 5930 (1969). 
${ }^{101}$ J. Horwitz and J. Heller, J. Biol. Chem. 249, 4712 (1974).

${ }^{102}$ P. J. Herring, Comp. Biochem. Physiol. 39B, 1039 (1971).

${ }^{103}$ B. A. Helm and P. F. Zagalsky, Unpublished observations.

${ }^{104}$ A. G. Andrews, G. Borch, S. L. Jensen and G. Snatzke, Acta. Chem. Scand. B28, 730 (1974).

${ }^{105}$ M. Kanai, A. Raz and D. S. Goodman, J. Clin. Invest. 47, 2025 (1968).

${ }^{106}$ P. A. Peterson and I. Beggard, J. Biol. Chem. 246, 25 (1971).

${ }^{107}$ S. Futterman and J. Heller, J. Biol. Chem. 247, 5168 (1972).

${ }^{108}$ P. A. Peterson and L. Rask, J. Biol. Chem. 246, 7544 (1971).

${ }^{109} \mathrm{D}$. Klinger and $M$. Karplus, as in ref. 110.

${ }^{110}$ B. Honig and T. G. Ebrey, Ann. Rev. Biophys، Bioengr. 3, 151 (1974).

${ }^{111}$ M. Takezaki and Y. Kito, Nature, Lond. 215, 1197 (1967).

${ }^{112}$ M. Azuma, K. Azuma and Y. Kito, Biochim. Biophys. Acta 351, 133 (1974).

${ }^{113}$ E. M. Johnson and R. Zand, Biochemistry 12, 4637 (1973).

${ }^{114}$ E. M. Johnson and R. Zand, Biochemistry 12, 4631 (1973).

${ }^{115}$ M. C. Gardiner and A. J. Thomson, Unpublished observations.

${ }^{116}$ C. A. Coulson and D. K. Davies, Trans. Faraday Soc. 48, 777 (1952).

${ }^{117}$ P. Y. Chou and G. D. Fasman, J. Mol. Biol. 74, 263 (1973).

${ }^{118}$ P. N. Lewis and H. A. Scheraga, Arch. Biochem. Biophys. 144, 576 (1971)

${ }^{119}$ P. N. Lewis and H. A. Scheraga, Biochim. Biophys. Acta. 336, 153 (1974).

${ }^{120}$ P. N. Lewis, F. A. Momany and H. A. Scheraga, Proc. Natn. Acad. Sci., U.S.A. 68, 2293 (1971).

${ }^{121}$ K. Nagano, J. Mol. Biol. 75, 401 (1973).

${ }^{122}$ G. Némethy and H. A. Scheraga, J. Phys. Chem. 66, 1773 (1962).

${ }^{123}$ J. C. J. Bart and C. M. MacGillavray, Acta Cryst. B24, 1587 (1968).

${ }^{124}$ S. J. Leach, G. Némethy and H. A. Scheraga, Biopolymers 4, 887 (1966).

${ }^{125}$ L. P. Vernon, B. Ke, H. H. Mollenhauer and E. R. Shaw, Prog. Photosynthetic Res. 1, 137 (1969).

${ }^{126}$ J. P. Thornber, J. C. Stewart, M. W. C. Hatton and J. Leggett-Bailey, Biochemistry 6, 2006 (1967).

${ }^{127}$ D. J. Haidak, C. K. Mathews and B. M. Sweeney, Science 152, 212 (1966).

${ }^{128}$ F. T. Haxo, J. H. Kycia, H. W. Siegelman and G. F. Somers, Abstr. 3rd Intern. Symp. Carotenoids, Clug. p. 73 (1972).
${ }^{129}$ H. G. Garewal and A. R. Wasserman, Biochemistry 13, 4072 (1974).

${ }^{130}$ J. O. Erickson and P. E. Blatz, Vision Res. 8, 1367 (1968).

${ }^{131}$ B. Ke, Meth. Enzym. 23, 624 (1971).

${ }^{132}$ C. Subbarayan and H. R. Cama, Indian J. Biochem. 3, 225 (1966).

${ }^{133}$ T. H. Ji, J. L. Hess and A. A. Benson, Biochim. Biophys. Acta 150, 676 (1968).

${ }^{134}$ F. A. McEvoy and W. S. Lynn, J. Biol. Chem. 248, 4568 (1973).

${ }^{135}$ A. Hager and H. Perz, Planta 93, 314 (1970).

${ }^{136}$ K. Shibata, Biochim. Biophys. Acta 22, 398 (1956).

${ }^{137}$ A. Hager, Planta 91, 38 (1970).

${ }^{138}$ R. L. Hall, M. C. Kung, M. Fu, B. J. Hales and P. A. Loaches, Photochem. Photobiol. 18, 505 (1973).

${ }^{139} \mathrm{U}$. Schwenker, M. St-Onge and G. Gingras, Biochim. Biophys. Acta 351, 246 (1974).

${ }^{140} \mathrm{U}$. Schwenker and G. Gingras, Biochem. Biophys. Res. Commun. 51, 94 (1973).

${ }^{141}$ D. Thirkell and M. I. S. Hunter, J. Gen. Microbiol. 58, 289 (1969).

${ }^{142}$ D. Thirkell and M. I. S. Hunter, J. Gen. Microbiol. 58, 293 (1969).

${ }^{143}$ D. Thirkell and M. I. S. Hunter, J. Gen. Microbiol. 62, 125 (1970).

${ }^{144}$ A. L. Tappel and C. J. Dillard, Lipids 3, 221 (1967).

${ }^{145}$ J. Glover, Vitams Horm. 31, 1 (1973).

${ }^{146}$ T. Hara and R. Hara, Nature, Lond. 242, 39 (1973).

${ }^{147}$ D. Oesterhelt, M. Meentzen and L. Schuhmann, Europ. $J$. Biochem. 40, 453 (1973).

${ }^{148}$ D. Bownds, Nature, Lond. 216, 1178 (1967).

${ }^{149}$ J. C. Saari, J. Cell Biol. 63, 480 (1974).

${ }^{150}$ L. Rask, Europ. J. Biochem. 44, 1 (1974).

${ }^{151} \mathrm{H}$. Schichi, M. S. Lewis, F. Irreverre and A. L. Stone, J. Biol. Chem. 249, 529 (1969).

${ }^{152}$ W. Stoeckeniusand W. H. Kanau, J. Cell Biol.38,337(1968).

${ }^{153} \mathrm{H}$. Muhilal and J. Glover, Trans. Biochem. Soc. 3(5), 744 (1965).

${ }^{154}$ L. Mateu, A. Tardieu, V. Luzzati, L. Aggerbeck and A. M. Scanu, J. Molec. Biol. 70, 105 (1972).

${ }^{155}$ J. P. Segrest, R. L. Jackson, J. D. Morrisett and A. M. Gotto, FEBS Lett. 38, 247 (1973).

${ }^{156}$ B. M. Gilchrist, P. F. Zagalsky and J. P. Prebble, Unpublished observations. 